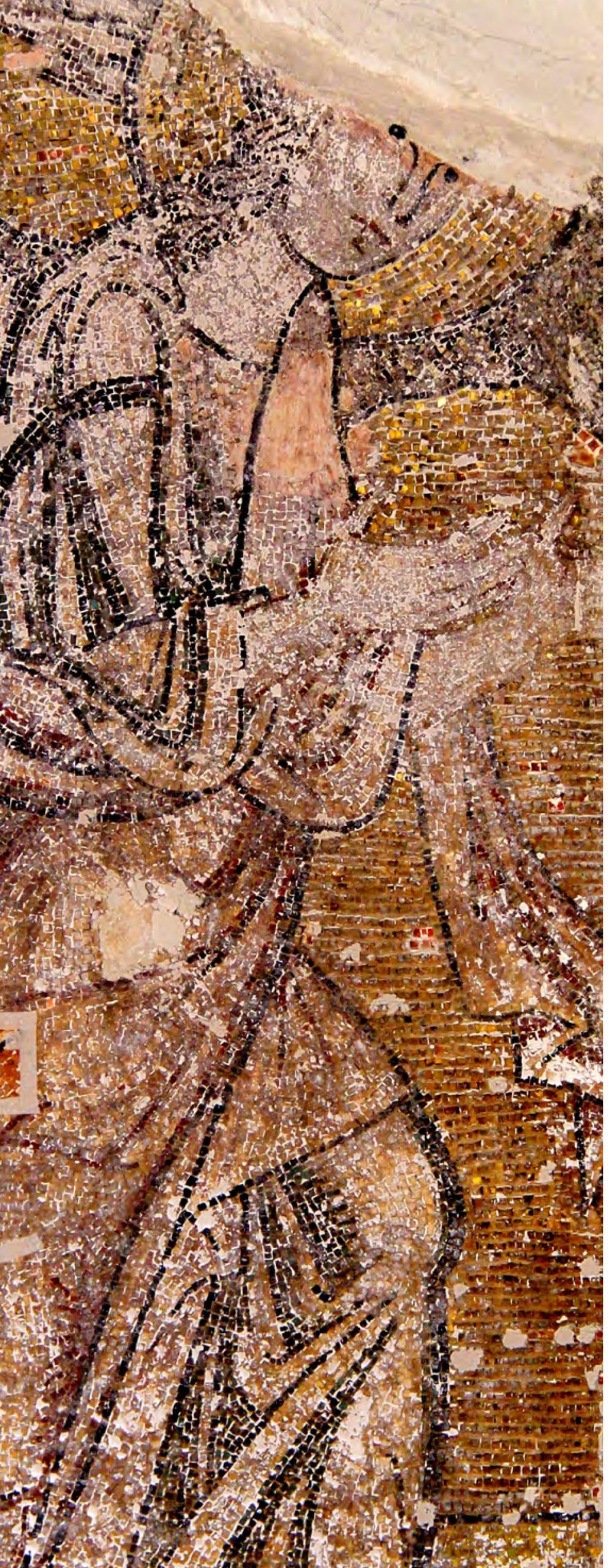

Abstract-Since 2010 the Nativity Church in Bethlehem underwent a number of significant restoration works, including the refurbishing of the wooden roof, the consolidation of the Armenian door, and, starting from March 2015, the cleaning and consolidation of the mosaic surfaces. This recent work lead to important discoveries, including the recovery of the figure of an angel which had been hidden under the plastering during the restoration made in 1842 . The present article describes and comments on the newly discovered and cleaned portions of mosaics and describes the history of the alterations underwent by them and by their architectural setting since the Crusader period up to our days.

Keywords-Bethlehem, Crusader art, pilgrimage, mosaics, Holy Land, holy sites, Byzantine art, restoration

Michele Bacci

Université de Fribourg michele.bacci@unifr.ch 


\section{Old Restorations and New Discoveries in the Nativity Church, Bethlehem}

Michele Bacci

In the last five years the Nativity Church in Bethlehem has been the object of a renewed interest, after a long period of neglect/Fig.1/. Any previous attempt at the making of repairs or other interventions within the Basilica was hampered by the delicate and often conflicting relations between the three communities (Greek Orthodox, Armenian, and Latin), whose specific rights and ownerships are defined by the not always limpid and often disputed rules of the status quo, as fixed by Sultan Abdül Mecid I in a firman promulgated in 1852 and still in force in our days. This set of rules and its interpretation were often a matter of controversy especially for the Franciscan and Armenian clergy, who made several efforts to challenge the preeminent role attributed in the text to the rights of the Greek Orthodox. Such disputes often extended to such matters as the right to clean, repair, and preserve the church and its furnishings.
As recorded in the so-called Cust Memoranduma meticulous description of the rights owned by each Christian denomination in the Palestinian holy sites which was worked out by the British officer Lionel G. A. Cust and the former Ottoman official Abdullah Effendi Kardus on request of the Mandatory Government in 1929 - in 1926 the urgent need to make some repairs to the roof caused enormous friction, as the Armenians and Franciscans made request to share the costs and therefore to infringe the Greek Orthodox's exclusive rights on any intervention involving the roof and nave. As the three groups proved unable to come to an agreement on this matter, "the repairs were carried out by the Government in the presence of representatives of the three Communities, and the incidence of the costs held in suspense" ${ }^{1}$.

1 Lionel G. A. Cust, The Status Quo in the Holy Places, London 1929, pp. 39-40. 


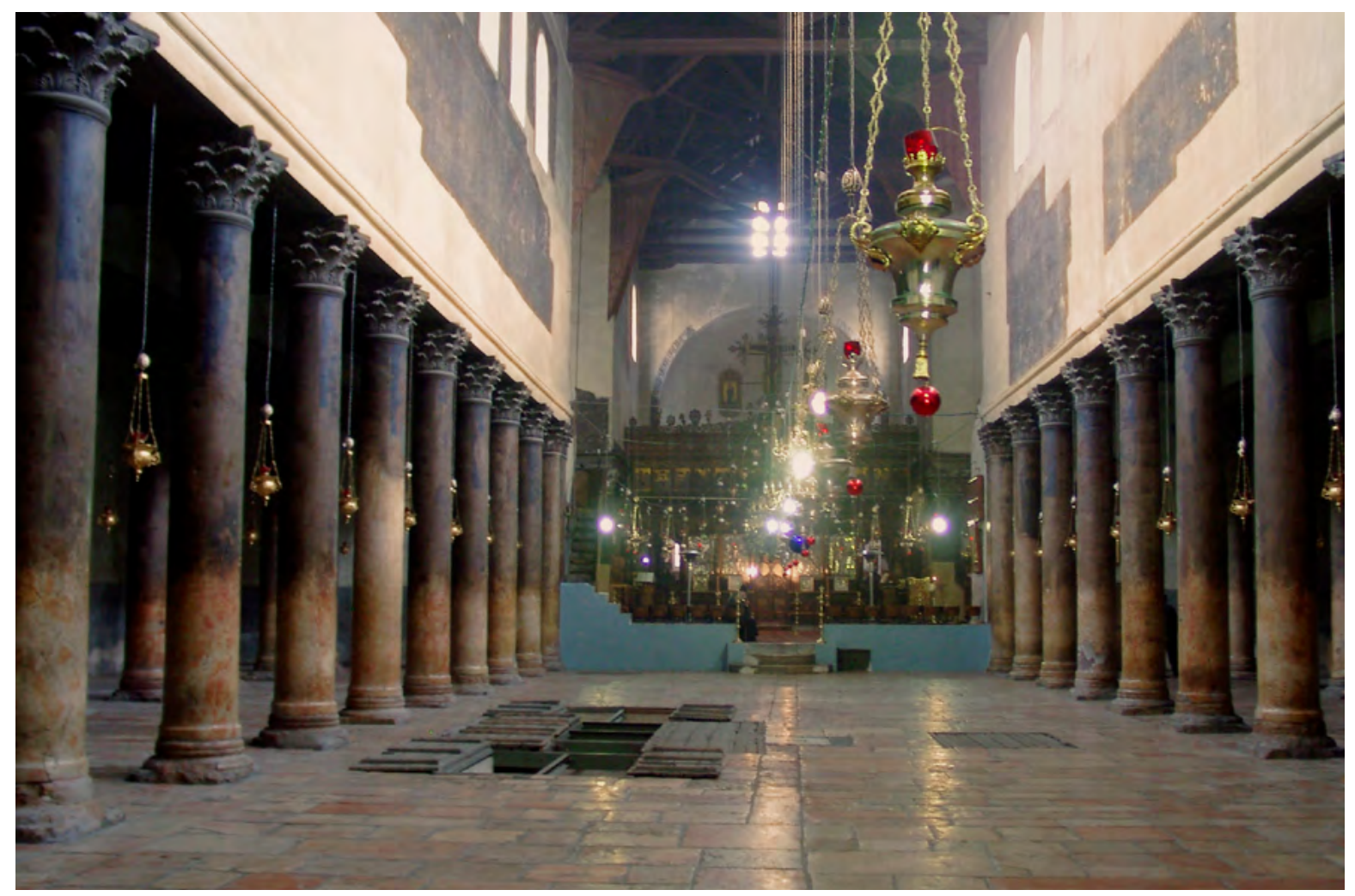

Rivalry between the different Christian denominations in the Holy Sites has a long history that also exerted a strong impact on the outward appearance of the building in the course of time. In the Crusader period all confessions owned the right to celebrate the mass at specific altars, even if Latin Christians, who had erected there a Bishopric and transformed the church status into that of a cathedral, played a hegemonic role. After Saladin's conquest of the city in 1187 , the building was left to Syriac-rite Christians, but already in 1192 the Latins were returned the right to perform their rites in the Basilica. In the thirteenth and fourteenth century, the place was officiated by Syriac-rite Melkites, Greeks, Western and Eastern Syrians, Armenians, Maronites, Copts, and Ethiopians ${ }^{2}$. These communities were even enabled to make repairs in the church: in 1227 the wooden door between the vestibule and the nave was carved with khatchkar-like crosses on the initiative of the Armenian community and with the involvement of two of its clergymen, Father Abraham and Father Arakel ${ }^{3}$.

Old sources witness that local Muslims also worshipped the place. The Franciscans are known to have been settled in Bethlehem by 1347, fol- lowing the 1333 agreement between the King of Naples Robert of Anjou and the Mamluke Sultan al-Nasir Muhammad ibn Qalawun, which bestowed the newly instituted Custody of the Holy Land with the ownership of a convent in the partly ruined structures having served as a residence for the cathedral canons in the Crusader period ${ }^{4}$. The friars gradually managed to obtain control over the most important altars: in the fifteenth century they had almost exclusive rights on the Nativity cave and the transepts ${ }^{5}$. Anyway, Franciscan hegemony started to be reduced after the Ottoman conquest of Palestine in 1517, as the Greek Orthodox clergy put more and more pressures on Turkish authorities in order to obtain recognition of their claims on the Holy Sites. Starting from the 1530s, pilgrims witness that the upper church was entirely in Greek ownership $^{6}$. In the seventeenth century, the Sublime Porte often wavered in favouring either the Latins or the Greeks, yet in 1637 Patriarch Theophanes III of Jerusalem obtained a firman recognizing his protest against Franciscan rights and in 1672 his successor Dositheos II was allowed to make repairs to the building in full autonomy. From 


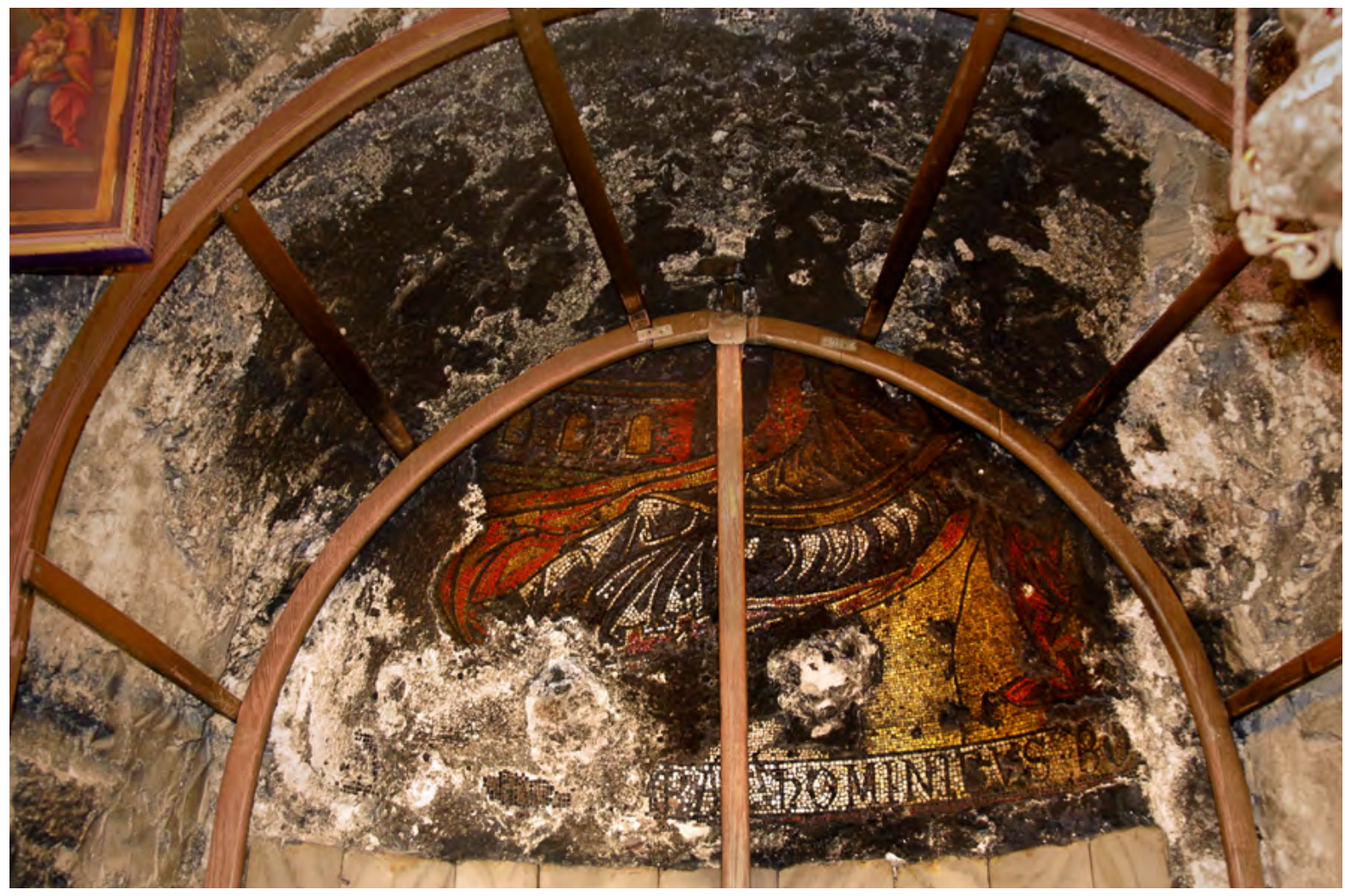

this period onwards, pressures were made on Turkish authorities in order to assert the exclusively Christian use of the building and to prevent Muslims from praying in the nave ${ }^{7}$.

Even if the Franciscans were returned their rights in 1690, the Greek Patriarchs' efforts were accomplished in 1757, when the Greek Orthodox were finally granted supremacy in both the church and the niche of Christ's birth in the Nativity cave, whereas the Latins were left with the manger, the cave of the Innocents and those of Saint Jerome. In 1813, however, the Armenians managed to obtain ownership of the north transept ${ }^{8}$, and later on the European powers put pressures on the Ottoman court to restore the Custody in its previous rights: this caused tensions which culminated in the removal by the Greeks of the silver star encircling the hole of Christ's birth in the grotto and bearing a Latin inscription, which could be used as argument to back Franciscan claims on the holy site. This accident was one of the sparks that caused the War of Crimea (1853-1856) to break out ${ }^{9}$.

The privilege of making repairs or displaying inscriptions was frequently regarded, especially from the fifteenth century onwards, as a strategy to assess control on the church: therefore any restoration proves still in our days to be inescapably charged with political implications. Anyway, it must be stressed that, in the course of time, the Nativity Church was preserved in largely better conditions than any other monument in the Holy Land. The last major refurbishing of the interior took place in the Crusader period, when the columns were partly decorated with mural icons of saints and the Virgin Mary, whereas an extensive mosaic program, as recorded in a bilingual inscription on the southern wall of the bema,

2 Denys Pringle, The Churches of the Crusader Kingdom of Jerusalem, Cambridge 1993-2009, vol. I, pp. 139-140.

3 Kevork Hintlian, History of the Armenians in the Holy Land, Jerusalem 1976, pp. 42-43; Michael E. Stone, "Epigraphica armeniaca hierosolymitana II", Annual of Armenian Linguistics, II (1981), pp. 72-73; Idem, "Epigraphica armeniaca hierosolymitana III", Revue des études arméniennes, XVIII (1984), pp. 559-560.

4 Leonhard Lemmens, Die Franziskaner im Hl. Lande. 1. Teil: Die Franziskaner auf dem Sion (1336-1551), Münster 1919, pp.57-60.

$5 \quad$ Ibidem, pp. 59, 152.

6 Denis Possot (1532): Le Voyage de la Terre Sainte composé par Maitre Denis Possot et achevé par Messire Charles Philippe, Charles H. A. Schefer ed., Paris 1890, p. 174

7 Oded Peri, Christianity under Islam in Jerusalem: The Question of the Holy Sites in Early Ottoman Times, Leiden 2001, pp.71-73.

8 Hintlian, History (n. 3), p. 42.

9 See, in general, Louis-Hugues Vincent, Félix-Marie Abel, Bethléem. Le sanctuaire de la Nativité, Paris 1914, pp. 195-205.
$1 /$ Interior of the Nativity Church, Bethlehem

2/The Nativity, mosaic, apse of niche of Child's birth, Nativity church, Bethlehem, $12^{\text {th }}$ century 
was carried out in the 1160s and accomplished in 1169 on the initiative of the Latin Bishop of Bethlehem Raoul (or Ralph), the Byzantine Emperor Manuel Comnenus (who was apparently the most munificent sponsor) and the King of Jerusalem Amalric with the involvement of at least two artists, Ephraim and Basilius the Deacon. The Byzantine Emperor's mosaic portrait - and perhaps also other images - could be seen nearby. The upper portions of the walls were embellished with compositions displaying the Tree of Jesse in the counterfaçade, the provincial councils of Palestine and the seven ecumenical councils accompanied by Christ's ancestors, decorative bands, and full-figure images of angels in the nave, a selection of Gospel scenes in the transept, the Annunciation in the triumphal arch and a Virgin Platytera flanked by Abraham and David in the apse. In the Ayyubid, Mamluke, and Ottoman periods the building underwent only minor changes, given that Christians were usually prevented from altering, enlarging or improving the material appearance of their churches and even ordinary repairs could take place only by formal authorization of the Sultan ${ }^{10}$.

This matter of fact contributed to enhance the renown of the Nativity church, whose relatively good state of preservation was described as a miracle and an outcome of God's special favour for some holy places of the Near East, namely the site of Christ's birth in Bethlehem, the monastery of Saint Catherine on Mount Sinai, and the church of Our Lady at Saidnaya, Syria, which were not only respected, but even worshipped by the Muslims ${ }^{11}$. Late medieval and early modern visitors were normally much impressed by the beauty of the church furnishings and more specifically by its combination of marbles and mosaics, which reminded them of San Marco in Venice or, less frequently, of Saint Peter in Rome ${ }^{12}$. The ancient Basilica was almost regularly said to be "of outstanding beauty and devotional appeal" (pulcherrima et devotissima) $^{13}$. Even if some visitors, being able to read the dedicatory inscription in the bema, were aware of the patronage of the King of Jerusalem and the Byzantine Emperor, some of them tended to imagine that the church decorum dated back to the times of Saint Helena's foundation. Even if most authors attributed the construction to Constantine's mother, alternative views evoked other figures of late Antiquity, such as King Trdat I of Armenia as the builder of the complex and Saint Jerome as founder of the nearby convent ${ }^{14}$. Another legend indicated that the church was built on the site of King Saul's palace ${ }^{15}$.

The sumptuousness of the interior was perceived as an exceptionally decorous frame to the Nativity cave and as a sort of emotionally charged, aesthetically appealing introduction to the site-specific sanctity of the place of Jesus' birth they were going to experience in the underground chapel. The upsetting beauty of the Basilica was in contrast with the tiny and dark appearance of the cave and the comparison played an important role in encouraging visitors to better sense the mystery of the Son of God's Incarnation enacted in such a humble, diminutive place. The Dominican Antonio of Cremona, who visited Palestine in 1326 and 1330, best describes the importance played by the church's lavish appearance in the pilgrim's experience of the site:

\footnotetext{
"In Bethlehem there is a church on the site where Christ was born, known as Saint Mary: it is so beautiful, that I never saw another one being so nice, so lavishly decorated, so magnificent in its columns and rich in paintings as this one in Bethlehem, which is taken as worship-worthy everywhere in the world. It would be extremely time-consuming to relate seriously and in detail the size, width, length of this worldwide famous church, the sequence of its many wonderful marble columns, the great number, order and distinctiveness of its paintings, its amazing pavement made of marble incrustations, its lead-covered roof. But let's leave aside such wordly aspects and let's speak only of the spiritual things which are in that outmost holy church" 16 .
}

Even if the decorations of the upper church were perceived as something "secular", which should not distract pilgrims from the authentic cultic attraction located underground, most of the visitors could not prevent themselves from praising the distinctive and unexpected beauty of the buildings, said to be unparalleled in the whole Christian world ${ }^{17}$. It must be stressed, anyway, that both spaces were marked out by lavish decorations: in the cave, the mosaic surface seems to have extended not only to the small apse of the 
niche of Christ's birthplace, decorated with the Nativity scene /Fig. 2/, but also to the vault of the cavern: according to the English pilgrim Richard Guylford, writing in 1506, the latter displayed "dyuers storyes", presumably narrative scenes ${ }^{18}$. The cave walls were reveted with marble plaques and precious stones ${ }^{19}$. Many of the finest marbles could be seen in the manger: pilgrims were able to associate a small column with the Virgin Mary, by imagining she had leant against it during her labour, and came to detect the image of Saint Jerome in the grey veins of a polished marble slab located nearby. A marble incrustation displaying a cross within a diadem marked the very spot where the rock had been touched by the Child Jesus' head ${ }^{20}$. The spot of Christ's birth was also embellished with marble incrustations, including a star-shaped design encircling a serpentine stone. At the beginnings of the sixteenth century, when the space was officiated by the Franciscans, it was decorated with a lunette-shaped altarpiece that covered the niche mosaic and represented the Nativity scene according to specifically Western conventions: Mary and Joseph were namely shown kneeling in front of the Child reclined on the floor, according to the Marian revelation experienced in 1373 by Saint Birgitta of Sweden within the Nativity cave ${ }^{21}$.

10 For a general survey of the history of the Church in Crusader times, see Pringle, The Churches (n. 2), vol. I, pp. 137-157.

11 Albericus de Tribus Fontibus (ca 1240-1250): Chronicon. Monumenta Germaniae historica. Scriptores rerum Germanicarum, Hannover 1826, vol. XXIII, pp.935-936.

12 The comparison with San Marco is frequently encountered. See, e.g., Eberhard im Bart (1461): Folker Reichert, “Eberhard im Bart und die Wallfahrt nach Jerusalem im späten Mittelalter. Ein unbekannter Pilgerbericht",Zeitschrift für württembergische Landesgeschichte, LXIV (2005), pp. 57-83, sp. p. 80; French anonymous (1480): Charles H. A. Schefer, Le voyage de la saincte cité de Hierusalem, Paris 1882, p. 80; Pierre Barbatre (1480): Pierre Tucoo-Chala, Noël Pinzuti, "Le Voyage de Pierre Barbatre à Jérusalem en 1480. Édition critique d'un manuscrit inédit", Annuaire-Bulletin de la Société de l'Histoire de la France, (1974), pp. 73-172, sp.p. 145; Santo Brasca, Viaggio in Terrasanta (1480): Viaggio in Terrasanta di Santo Brasca, 1480, con l'Itinerario di Gabriele Capodilista, 1458, Anna Laura Momigliano Lepschy ed., Milan 1966, pp. 45-150, sp. p. 100; Konrad Grünenberg, Pilgerreise ins Heilige Land (1486): Andrea Denke, Konrad Grünenbergs Pilgerreise ins Heilige Land. Untersuchung, Edition und Kommentar, Cologne/Weimar/Vienna 2011, p. 442. For a comparison with Saint Peter in Rome see Pietro Paolo de' Rucellai: Viaggio di oltramare di frate Pietro Paolo dei Rucellai dell'osservanza di San Francesco, Marcellino da Civezza ed., in Saggio di bibliografia geografica, storica, etnografica sanfrancescana, Prato 1879, pp. 507-514, sp.p. 512.

13 See, e.g., Francesco Pipino (1320): Luigi Manzoni, Frate Francesco Pipino da Bologna de' pp. Predicatori, geografo storico e viaggiatore, Atti e memorie della R. Deputazione di storia patria per le provincie di Romagna, ser. III, XIII (1895), pp. 256-334, sp.p. 317.
14 The attribution to Trdat appears only in Johann Schildtberger's travelogue (1394-1427): Johannes Schiltberger, Hans Schiltbergers Reisebuch nach der Nürnberger Handschrift, Valentin Langmantel ed., Tübingen 1885, p. 87. On Saint Jerome's alleged construction of the Franciscan convent see Duke Alexander of Palatinate-Zweibrücken (1495-1496): Jürgen Karbach, “Die Reise Herzog Alexanders von Pfalz-Zweibrücken und Graf Johann Ludwigs von Nassau-Saarbrücken ins Heilige Land, 1495-1496, nach dem Bericht des Johann Meisenheimer", Zeitschrift für die Geschichte der Saargegend, LX (1997), pp.11-118, sp. p. 78; Hans Schürpff, Peter Wachter: Luzerner und Innerschweizer Pilgerreisen zum Heiligen Grab in Jerusalem vom 15. bis 17. Jahrhundert, Josef Schmid ed., Luzern 1957, p. 26; Pantaleão d'Aveyro, Itinerario da Terrasancta e suas particularidades, Lisbon 1593, fol. 150v-151v.

15 Schürpff and Wachter:Luzerner und Innerschweizer Pilgerreisen (n. 14), p. 26.

16 Fra' Antonio de' Reboldi da Cremona: "Itinerarium ad sepulchrum Domini $(1327,1330)^{\prime \prime}$, Reinhold Röhricht ed., Zeitschrift des deutschen Palästina-Vereins, XIII (1890), pp. 153-174, sp.p. 160.

17 Wilhelm von Boldensele: Liber de quibusdam ultramarinis partibus et praecipue de Terra Sancta (1336), suivi de la traduction de frère Jean le Long (1350), Christiane Deluz ed., PhD thesis (Université de Paris IV-Sorbonne), Paris 1972, p. 244: "Apparet mihi quod nunquam magis gratiosam ecclesiam viderim in hoc mundo...".

18 Richard Guylforde (1506): Henry Ellis, The Pylgrimage of Sir Richard Guylforde to the Holy Land, A. D. 1506, London 1851, p. 37.

19 See, e.g., Coppart de Velaine (1431-1432): Jacques Paviot, "Le manuscrit Tournaisien «Coppart de Velaines» (BNF, ms. nouv acq. fr. 10058)", in Campin in Context. Peinture et société dans la vallée de l'Escaut à l'époque de Robert Campin 1375-1445, Ludovic Nys, Dominique Vanwijnsberghe eds, Valenciennes/Brussels 2007, pp. 277-309, sp.p.305:“...une tres bielle capielle vossee, tres noblement pointe d'or, d'asur, de pierez"; Donaueschingen Anonymous (1441-1442): Randall Herz, Fünf Palästina-Beschreibungen aus dem 15. Jahrhundert, Wiesbaden 1998, pp.151-174, sp.p.169; Roberto da Sanseverino, Viaggio in Terrasanta (1458-1459): Felice et divoto ad Terrasancta viagio facto per Roberto de Sancto Severino (1458-1459), Mario Cavaglià, Alda Rossebastiano eds, Alexandria 1999, p. 156:“...una longa et bella capella nominata Capella Sancta, lavorate de musaicho et bellissimo lavore"; Louis de Rochechouart (1461): “Journal de voyage à Jérusalem de Louis de Rochechouart éveque de Saintes (1461)", Camille Couderc ed., Revue de l'Orient latin, I (1893), pp. 168-274, sp.p. 261; Felix Fabri, Evagatorium in Terrae Sanctae, Arabiae et Egypti peregrinationem, Konrad Dieterich Hassle ed., Stuttgart 1843-1849, vol. I, p. 484: “Super omnia autem specus nativitatis subtus chorum est pretiosissimis pavimentis et tabulaturis ornatus et picturis"; Michele da Figline (1489-1490): Marina Montesano, Da Figline a Gerusalemme. Viaggio del prete Michele in Egitto e in Terrasanta (1489-1490), Rome 2010, p.126: "la cappella è lungha passi 20 et largha passi 5 et alta sej, tutta coperta di marmo et la volta è di musaicho"; Francesco Suriano, Il Trattato di Terra Santa e dell'Oriente, Milan 1900, p. 123: “Tuto questo diversorio è fodrato le mura de tavole de marmaro finissimo, ma lo zielo de sopra de la volta e lo pavimento de soto tuto è de mosaico". A very detailed description of the different marbles and ornaments in the Nativity cave is given by Nicholas de Farnad, Compendiosa quedam nec minus lectu iocunda descriptio urbis Hierusalem atque diligens omnium locorum Terre Sancte in Hierosolymis adnotatio, Vienna [ca 1519], f. 19r. See Bellarmino Bagatti, Gli antichi edifici sacri di Betlemme, Jerusalem 1952, pp.123-124.

20 A very detailed description occurs in Niccolò da Poggibonsi, Libro d'Oltramare, Antonio Lanza ed., in Pellegrini scrittori. Viaggiatori toscani del Trecento in Terrasanta, Antonio Lanza, Giuseppina Troncarelli eds, Florence 1990, pp.31-158, sp.p.81, followed almost word by word by Girolamo Castiglione, Fior de terra sancta noviter impressa, Messina 1499, f. 20r. On the acheiropoieton of Saint Jerome see Bagatti, Gli antichi edifici (n. 19), pp.121-122; Michele Bacci, "Remarks on the Visual Experience of the Holy Sites in the Middle Ages", in Mobile Eyes. Peripatetisches Sehen in den Bildkulturen der Vormoderne, David Ganz, Stefan Neuner eds, Munich 2013, pp. 175-197, sp. pp. 182-184.

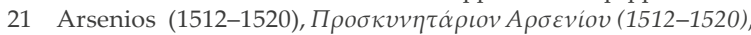
G. Mavrommates, G. Arvanitakes eds, Alexandria 1899, pp. 485-490; Bernardino Amico, Trattato delle piante et imagini de $i$ sacri edifici di Terrasanta, Rome 1609, p. 8. The image was reproduced in an engraving by Natale Bonifacio included in Jean Zuallart, Il devotissimo viaggio di Gierusalemme, Rome 1595, p. 208. See also the latter's description on p. 209. 
In any case, most descriptions laid more emphasis on the sumptuous appearance of the upper Basilica. Pilgrims were fascinated by the floor composed of black and white square plaques and by the multi-coloured marble revetments of the lower portions of the nave walls ${ }^{22}$ : such ornaments were not rarely described as the most distinctive elements of the church interior, without any hint at the mosaic decoration ${ }^{23}$. The elongated, noble columns of the nave and their elaborate capitals were much admired and said to be made of jasper ${ }^{24}$. The elevated choir was encircled by a rather high wall screen, provided with doors on the eastern, northern and southern sides ${ }^{25}$.

The wooden roof, covered with lead, was perceived as something very rare and precious and was even taken by somebody as being very old, dating back to the foundation of the church by Saint Helena in the fourth century, as with all other church ornaments and furnishings ${ }^{26}$. The mosaics decorating the nave, the transepts and the apse stood out, in their eyes, especially for their preciousness: many pilgrims remarked that they were made not only of gold, but also of azure tesserae $^{27}$. Anyway, some visitors went so far as to appreciate their technical refinement: "On the walls above the columns", writes the English anonymous of 1344, "there are images whose beauty, in my opinion, is unparalleled in the entire world: they are made of small square stones which are put together as wall inserts of different colours, in the way they prove to be more suitable for the work"28. Emphasis was also laid on the presence of both Greek and Latin monumental inscriptions: the dedicatory one in the choir was transcribed in several texts ${ }^{29}$. In contrast with the rather dilapidated state of other Palestinian churches, the Bethlehem church looked like a sort of miraculously well preserved building, whose sumptuous appearance came to be described even in mythical terms, as if it were thoroughly decorated with marble, ivory, and jasper, as a Catalan anonymous put it in $1323^{30}$. In 1476 a German visitor wondered why the Franciscans alleged that there was no beautiful church in Palestine, given that the Bethlehem Basilica proved them wrong ${ }^{31}$.

Several authors laid emphasis on the multifarious materials used to embellish the building: in Ludolph of Südheim's account (1336-1341), the latter's description as a "beautiful and enormous church, decorated with mosaics and marbles, whose walls are painted in gold and covered with crystal and glass tesserae, as well as with a very noble and decorous imagery" probably hinted at a technical peculiarity of the Bethlehem mosaics, their being made of glass and stone with many mother-of-pearl inserts ${ }^{32}$. The extension of the painted program was also a most remarkable sign of distinction: many pilgrims, starting with Wilhelm of Boldensele (1336), were stricken by an iconographic peculiarity, the representation of Christ's genealogy ${ }^{33}$, sometimes misinterpreted as displaying the Old Testament prophets who had announced the advent of the Messiah ${ }^{34}$. Niccolò da Poggibonsi (1346) was the first to mention the Tree of Jesse and the representation of the Virgin Mary flanked by Abraham and David in the apse, whereas Louis de Rochechouart, Bishop of Saintes (1461) was able to identify the provincial councils on the north wall as images of the cities of Judaea ${ }^{35}$. Girolamo Castiglione's reworking of Niccolò da Poggibonsi's text seems to imply (but probably by mistake) that the scene of Christ's Baptism may have been located close to the genealogy according to Luke $(3,23-38)$ on the north wall ${ }^{36}$.

Other authors interpreted the program as displaying a complete set of stories from the New and Old Testaments ${ }^{37}$. The Greek Metropolitan Daniel of Ephesus, who visited the Holy Land in 1480, was glad to see that the most important churches of the Holy Land, including the Holy Sepulchre and the Nativity Church, were embellished with religious images according to Byzantine conventions. Even if he was able to read the inscription in the bema and recognize the portrait of Emperor Manuel Comnenus in the nearby wall, he interpreted all Palestinian wall mosaics as expressions of a very old tradition dating back to Constantinian times and bearing witness to the iconodulic attitudes of the Early Christian church ${ }^{38}$.

Anyway, from the late fourteenth century onwards, a number of pilgrims' accounts started pointing out that the church, even if it still proved to be the most beautiful Christian building in the Holy Land, was partly in a state of decay because 
of lack of maintenance and frequent plunders. Whereas Niccolò da Poggibonsi just signaled that some chairs within the walled choir were damaged $^{39}$, Nicola de' Martoni, in 1395 , was the first to lament that the architectural complex had been bigger before some of its parts, especially in the ancient atrium and the Franciscan convent, were damaged or demolished ${ }^{40}$. The old atrium still preserved its ancient portal in the second half of the sixteenth century, but the rest of the architectural remnants were ruined and a structure with columns, said to be the "School of Saint Jerome", was used as a stable ${ }^{41}$.

In 1395, Count Ogier of Anglure remarked that the church had once been much more beautiful than it was in his days ${ }^{42}$. Other visitors lamented that the nearby buildings were mostly ruined, whereas the church was losing some of its beautiful ornaments. The complex was located in a village which appeared to be in a thoroughly ruined state and was inhabited by rough countrymen: according to Roberto da Sanseverino (1459) and later authors, the church rising within a decaying context was nonetheless still beautiful, even if no longer as gorgeous and astonishing as in

22 See Humbert de Dijon, Le Liber de locis et conditionibus Terrae Sanctae: Thomas Kaeppeli, Pierre Benoit eds, “Un pèlerinage dominicain inédit du XIV ${ }^{\mathrm{e}}$ siècle, le Liber de locis et conditionibus Terrae sanctae et Sepulchro d'Humbert de Dijon O. P. (1332)", Revue biblique, LXII (1955), pp. 516-540, sp. p. 526: “...est tota pulchre pavimentata de marmore nigro et albo, disposito valde pulchre"; Franciscan Anonymous (1463): Charles Kohler, "Description de la Terre Sainte par un Franciscain anonyme 1463", Revue de l'Orient latin, XII (1909-1911), pp.1-59, sp. p.31: “...pavimentumque marmoreo tabulatu mirifico non modo stratum est, quin et pars inferior parietum lucidiori marmore exornata est"; Brasca, Viaggio (n. 12), p. 207: "El pavimento suo, cyoè il saligato, è tutto di marmo bianchissimo"; Bernardino Dinali, Ierosolimitana peregrinatione (1492): La"jerosolomitana peregrinatione" del mercante milanese Bernardino Dinali (1492), Ilaria Sabbatini ed., Lucca 2009, p. 104: "El pavimento di essa tucto di candidi marmi è coperto, le mura da la parte interiore marmi di diversi finissimi colori cuopreno"; de Farnad, Compendiosa descriptio (n. 19), f. 18r: "pavimentum in toto de lapidibus marmoreis quadratis, aliquibus albis, aliquibus subnigris".

23 Itinerario de andare in Hierusalem (1469): Lo itinerario de andare in Hyerusalem (1469). Loca sancta visitanda in partibus Jerusalem. Ms. G. 10 - Biblioteca del Seminario Vescovile di Casale Monferrato, Pier G. Longo ed., Ponzano Monferrato 2007, p. 185: "dicta eclexia tuta ornata di tavole di marmore"; Flemish Anonymous (ca 1470): Ludwig Conrady, Vier rheinische Palästina-Pilgerschriften des XIV., XV. und XVI. Jahrhunderts, Wiesbaden 1882, pp.72-181, sp.p. 144; Duke Albrecht of Saxony (1470): Gründliche und warhafftige beschreibung der löblichen und ritterlichen Reise und Meerfart in das heilige Land nach Hierusalem des Durchlauchtigen und Hochgebornen Fürsten unnd Herrn Herrn Albrechten Hertzogen zu Sachssen, Hieronymus Weller ed., Leipzig 1586, p. 95: "Und ist von Marmelstein mancherley farben so köstlich gebawet, das man ires gleichen schier in der Welt nicht findet..."; Juan del Encina, Viaje a Jerusalén: Juan del Encina. Obras completas, Ana M. Rambaldo ed., Madrid 1978, vol. II, p. 233: "La iglesia es muy bella, de bellas colunas/ y mármores lindos, mas no qual conviene, / que bien tan precioso ningún precio tiene, / y a cosas tan altas igualan ningunas".

24 English Anonymous (1344): Girolamo Golubovich, Biblioteca Bio-Bibliografica della Terra Santa e dell'Oriente Francescano, Quaracchi 1923, vol. IV, pp. 427-460, sp. p. 457.

25 As witnessed by Niccolò da Poggibonsi (1346): Libro d'Oltramare (n. 20), p. 81.

26 Mariano da Siena (1431), Viaggio fatto al Santo Sepolcro 1431, Paolo Pirillo ed., Pisa 1991, p. 113.

27 Gabriele Capodilista (1458): Viaggio in Terrasanta (n. 12), p. 207; Ulrich Leman: Monika Reininger, Ulrich Lemans Reisen. Erfahrungen eines Kaufmanns aus St. Gallen vom Ende des 15. Jahrhunderts im Mittelmeer und in der Provence, Würzburg 2007, p. 81; Fabri, Evagatorium (n. 19), vol. I, p. 469: “...et murus ille a columnis usque ad fenestras est non de pictura, sed de lasura, et opere musaico mirabili arte ornatus ab utraque parte, sicut S. Marci Venetiis, cum figuris novi testamenti et concordantiis figurarum veteris Testamentis, et tota ecclesia in omnibus parietibus vel est marmore candido polito tecta vel opere musaico decorata"; Ambrosius Zeebout, Tvoyage van Mher Joos van Ghistele (1481-1485), R. J. G. A. A. Gaspar ed., Hilversum 1998, p. 102.

28 English Anonymous (1344): Golubovich, Biblioteca (n. 24), vol. IV, p. 457.

29 James of Verona, Liber peregrinationis (1335): Liber Peregrinationis di Jacopo da Verona, Ugo Monneret de Villard ed., Rome 1950, p.62; de Rochechouart (1461): “Journal de voyage" (n. 19), p. 260; Daniel of Ephesus (1480): Православний Палестинский Зборник, III/2 (1884), G. Destunis ed., pp. 1-23, sp.p. 19.

30 Catalan Anonymous (1323): “Un nou viatge a Terra Santa en catalá", Joseph Pijoan ed., Anuari de l'Institut d'estudis catalans, (1907), pp.307-384, p.376.

31 Ludwig von Eyb the Younger (1476): Christian Geyer ed., "Die Pilgerfahrt Ludwigs des Jüngeren von Eyb nach dem Heiligen Lande (1478)", Archiv für Geschichte und Altertumskunde von Oberfranken, XXI (1901), pp. 1-54, sp. p. 40: "Item es sprechen dye parfusser, das dy Kristen in aller heydenschaft kein schone kyrchen nit haben, wann sie ist weyt und gros und gemacht von eytel merbelstein...".

32 Ludolph of Südheim: "Ludolphus de Sudheim de itinere Terrae Sanctae", Guillaume A. Neumann ed., Archives de l'Orient latin, II/2 (1884), pp.305-377, sp. p. 349.

33 Wilhelm von Boldensele: Liber de quibusdam (n. 17), p. 243. Many later pilgrims hint only at the representations of Christ's ancestors in the lower portions of the nave mosaics: cf., e.g., Johannes Poloner, Descriptio Terrae Sanctae (1422): Titus Tobler, Descriptiones Terrae Sanctae ex saeculo VIII. IX. XII. et XV., Leipzig 1874, pp. 225-281, sp. p. 248.

34 Jean Thenaud (1512), Le voyage d'outre-mer (Egypte, Mont Sinay, Palestine) de Jean Thenaud, gardien du couvent des Cordeliers d'Angoulême, suivi de la relation de l'ambassade de Domenico Trevisan auprès du Soudan d'Egypte, 1512, Charles Schefer ed., Paris 1884, pp.90-91.

35 Da Poggibonsi: Libro d'Oltramare (n. 20), p. 81; de Rochechouart: "Journal de voyage" (n. 19), pp. 259-260.

36 Castiglione, Fior de Terra Sancta (n. 20), f. 19v-20r: "Alla parte sinistra della nave si è figurato tute le generatione che contieneno nel evangelio che dice Factum est cum omni populo baptizaretur. Evidesi Christo come fu baptizato. Cominçaba a Heli e a Matar per fin ad Adamo. E questo lavorìo è tuto d'opera mosaica".

37 Wilhelm Tzewers (1477-1478): Gritje Hartmann, Itinerarium Terrae Sanctae: Wilhelm Tzewers: Itinerarius terre sancte. Einleitung, Edition, Kommentar und Übersetzung, Wiesbaden 2004, p. 262; Hermann Sina (1478), Prologus Arminensis in mappam Terrae Sanctae, Wilhelm-Anton Hartmann ed., Geneva 1885, n. p.

38 Daniel of Ephesus (1480): Православний (n. 29), p. 11, 19.

39 Da Poggibonsi : Libro d'Oltramare (n. 20), p. 81.

40 Nicola de Martoni, Liber peregrinationis: Io Notaio Nicola de Martoni. Il pellegrinaggio ai Luoghi Santi da Carinola a Gerusalemme 1394-1395 (Paris - Bibliothèque Nationale N. 6521 du Fonds Latin), Michele Piccirillo ed., Jerusalem 2003, p.72.

41 Luigi Vulcano, Vera et nuova descrittione di tutta Terra Santa, et peregrinaggio del sacro monte Sinai, Naples 1563, p. 79.

42 Ogier d'Anglure (1395): Le saint voyage de Jhérusalem du seigneur d'Anglure, François Bonnardot, Auguste Longnon eds, Paris 1878 , p. 31. 
the times past ${ }^{43}$. Anselme Adornes (1470) noticed that the building had lost some of its towers and walls ${ }^{44}$. Some damage may have been caused by an earthquake which took place sometimes between 1456 and 1459, even if the German pilgrim Hans Bernhard von Eptingen specified that the church came out of that accident miraculously unharmed $^{45}$. In 1489-1490 Michele da Figline stated that part of the church had recently collapsed, but it may be that he hinted in this way at the static problems of the wooden roof (see below). He also reported that the indigenous population was accustomed to pull down the extant columns in the atrium in order to steal the latter's lead elements ${ }^{46}$. According to other texts, some stones were used as building materials for private houses in the village ${ }^{47}$.

Some authors, such as Domenico Messore in 1440, accused the Mamluke authorities of both plundering the church and prohibiting to make any kind of repair ${ }^{48}$. Indeed, the walls and the pavement were gradually divested of their precious marble revetments, which, as the Greek pilgrim Daniel of Ephesus observed in 1480-1481, were extremely rare in Palestine ${ }^{49}$. This matter of fact is echoed and expressed in legendary terms by the curious story, first told by Burchardus of Mount Zion in the thirteenth century and repeated by almost all subsequent visitors to Bethlehem until the eighteenth century, concerning an enormous snake that had appeared to prevent a Sultan, willing to embellish his own palace in Cairo, from removing a precious marble slab and had left the imprint of its body on the surface ${ }^{50}$. In 1463 eighteen marble plaques, said to have been broken by the snake, were shown in the church interior ${ }^{51}$. In 1512, the Greek pilgrim Arsenios was able to see some extant slabs in the bema and choir, whereas the nave had been by then completely deprived of them ${ }^{52}$. Twenty years later, the Minor Friars were authorized by Suleiman the Magnificent to refurbish the walls with new marble plaques, but apparently they did not succeed in raising funds for the restorations ${ }^{53}$. In the seventeenth century, visitors could only see some of the fasteners which had originally been used to affix the plaques to the walls ${ }^{54}$. Moreover, Felix Fabri considered that cave, may have been caused by the popular belief about treasures said to be hidden below the floor and went so far as to accuse non-Latin Christians in Bethlehem of looting the building and selling marble plaques to the Muslims ${ }^{55}$.

Serious damage affected the wooden roof, especially in the area overlooking the choir, probably as an outcome of the earthquake in the late 1450s. Even previously it had become clear that the structure had become very unsteady: some refurbishments were made in 1411 and 1435, and in 1448 Pope Nicholas v granted Duke Philip of Burgundy the right of sending carpenters and wooden beams to Bethlehem ${ }^{56}$. Nevertheless, no works were accomplished in the following decades and in 1461 Louis de Rochechouart was afraid that part of the roof was quickly going to collapse ${ }^{57}$. Shortly later, in 1474, the Franciscan friars erected a sort of wooden scaffolding to support the ceiling in the choir zone ${ }^{58}$, and in 1479 the Father Guardian of Bethlehem Giovanni Tomacelli was authorized by the Sultan to make repairs. Tomacelli was an Observant friar and his efforts to restore the basilica's ancient decorum manifested a radical change of attitude, implicitly contrasting that of the previous Conventual administration (as is implied by Francesco Suriano's words $)^{59}$. He was able enough to obtain sponsorships from the Duke of Bourgogne and the King of England; whereas the latter's money was used for the lead covering, the former's was invested for the making of the new wooden structure. Venetian carpenters and wood-carvers came to Bethlehem to take measurements and they subsequently made beams out of pinewoods from the Alps. The materials were transported by ship to Jaffa and thence transferred to Bethlehem by means of camels and oxen; special machines were constructed in order to transport the hugest and longest beams. The latter were seen by an anonymous French pilgrim in a space located close to the Basilica in $1480^{60}$. The reparation works were accomplished in the 1490 s at the very latest, so that the building could temporarily be sheltered from both rain and mute ${ }^{61}$.

The first explicit records about the decaying state of the mosaics date from the 1460s. Louis de Rochechouart remarked that the beautiful images 
in the nave, representing the cities of Judaea and the genealogy of Christ, were mostly darkened and hard to see, whereas the apse figure of the Virgin Mary was going to fall down, as if it had been torn out of the wall ${ }^{62}$. The situation in the cave looked no less problematic: the mosaics in the vault and in the small apse of the Nativity chapel were still complete, but thoroughly darkened by the smoke of candles and lamps ${ }^{63}$. The German pilgrim Gaudenz von Kirchberg (1470) remarked, with some exaggeration, that the beautiful images in the nave were "almost destroyed" ${ }^{\prime \prime 4}$. The words by Pierre Barbatre (1480), stressing that the Basilica had once been thoroughly painted like San Marco in Venice, seem to imply that a number of mosaics had started by then to fall down ${ }^{65}$. Richard Guylforde (1506) was much impressed by the overall effect of the mosaics, which he described as "the richest thynge that can be done to any wallys". Yet, the decoration in the nave and in the Nativity chapel were both strongly defaced "for very pure age" and in general the church appeared to be in great decay ${ }^{66}$. The somewhat deceiving appearance of the decoration may have been enhanced by their inadequate illumination, given that the sunlight hardly filtered through the partly plastered windows. At the same time, attempts were made at abrading the golden tesserae: local Muslims were accused of spoiling the work ${ }^{67}$. Even the paintings on the columns were hardly visible: a German pilgrim regarded them as almost miraculous objects, which showed "wonderful forms and figures" when closely inspected ${ }^{68}$.

In the sixteenth century, notwithstanding such damages, most visitors were still astonished at the beauty and width of the mosaic decoration: the Spanish knight Don Fadrique Enríquez de Ribera (1518-1520) witnessed that the nave, the main apse and the transepts were still more or less covered with an unbroken painted surface ${ }^{69}$. They often presumed that the wall images displayed a very complex and thorough program of sacred narratives from the Creation of the World

43 Roberto da Sanseverino, Viaggio in Terrasanta (n. 19), p. 155; Piero Antonio Buondelmonti (1468), L'Itinerario di Piero Antonio Buondelmonti, 1468, Andrea Calamai ed., Pisa 1993, p. 255; Ulrich Brunner (1470): Reinhold Röhricht, “Die Jerusalemfahrt des Kanonikus Ulrich Brunner vom Haugstift in Würzburg (1470)", Zeitschrift des deutschen Palästina-Vereins, XXIX (1906), pp.1-50, sp.pp. 42-43.
44 Anselme Adornes, Itinerarium Terrae Sanctae: Itinéraire d'Anselme Adorno en Terre Sainte (1470-1471), Jacques Heers, Georgette de Groer eds, Paris 1978, p. 286. "Numquam magis tam graciosam ecclesiam in Sancta Terra et tam delectabilem me vidisse memini, licet aliqualiter nunc sit in aliquibus suis turribus ac muris ac propugnaculis rupta".

45 Hans Bernhard von Eptingen (1460): Dorothea A. Christ, Das Familienbuch der Herren von Eptingen. Kommentar und Transkription, Liestal 1992, p. 261. On the earthquakes recorded between 1456 and 1459 see David H. K. Amiran, E. Arieh, T. Turcotte, “Earthquakes in Israel and Adjacent Areas: Macroseismic Observations since 100 в. C.", Israel Exploration Journal, XLIV (1994), pp. 260-305, sp.pp. $270-271$.

46 Michele da Figline: Montesano, Da Figline a Gerusalemme (n. 19), p. 125.

47 Heinrich Stultz (1519): Luzerner und Innerschweizer Pilgerreisen (n. 14), p. 244

48 Domenico Messore: Viagio del Sancto Sepolcro di Milliaduse d'Este (1440): Viagio del Sancto Sepolcro facto per lo illustro misere Milliaduxe estense, Beatrice Saletti ed., Rome 2009, p. 83.

49 Daniel of Ephesus (1480): Православний (n. 29), p. 19. The plundering of marble plaques is witnessed already in 1422 by Johannes Poloner: Tobler, Descriptiones Terrae Sanctae (n. 33), p. 248.

50 Burchardus de Monte Sion: Descriptio Terrae Sanctae: Itinera hierosolymitana Crucesignatorum, Sabino De Sandoli ed., Jerusalem 1978-1984, vol. IV, pp. 119-220, sp.pp. 196-198. Gabriele Capodilista (1458) was struck by the intensive white colour of the church marbles: Viaggio in Terrasanta (n. 12), p. 207. On the snake legend cf. Titus Tobler, Bethlehem in Palästina topographisch und historisch nach Anschau und Quellen geschildert, St. Gallen/Bern 1849, pp. 87-88; Bagatti, Gli antichi edifici (n. 19), p. 58.

51 Franciscan Anonymous (1463): Kohler, “Description de la Terre Sainte" (n. 22), p. 32.

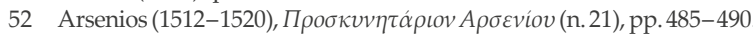

53 Lemmens, Die Franziskaner (n. 4), p. 211.

54 Blas de Buysa, Relación nueva, verdadera y copiosa de los sagrados lugares de Jerusalén y Tierrasanta, Madrid 1622, f. 25r; Francesco Quaresmi, Historica, theologica et moralis Terrae Sanctae elucidatio, Antwerp 1639, vol. II, p. 643.

55 Fabri, Evagatorium (n. 19), vol. I, p. 476.

56 Lemmens, Die Franziskaner (n. 4), pp. 95, 119.

57 Louis de Rochechouart (1461): “Journal de voyage" (n. 19), p. 259.

58 Alessandro di Filippo Rinuccini, Sanctissimo peregrinaggio del Sancto Sepolcro 1474, Andrea Calamai ed., Pisa 1993, p. 142.

59 Suriano, Il Trattato (n. 19), p. 190.

60 French anonymous (1480): Schefer, Le voyage de la saincte cité (n. 12), p. 80 .

61 Fabri, Evagatorium (n. 19), vol. I, pp. 477-478; Alexander of Palatinate (1495-1496): Karbach, “Die Reise” (n. 14), pp. 78-79. Cf. Lemmens, Die Franziskaner (n. 4), pp. 108, 118-120, 128-129; Bagatti, Gli antichi edifici (n. 19), pp. 55-56.

62 De Rochechouart (1461), “Journal de voyage” (n. 19), pp. 259-260.

63 Ibidem, p. 261.

64 Gaudenz von Kirchberg (1470): Reinhold Röhricht, “Jerusalemfahrt des Grafen Gaudenz von Kirchberg, Vogtes von Matsch (1470)", Forschungen und Mitteilungen zur Geschichte Tirols und Voralbergs, II (1905), pp. 97-152, sp. p. 139

65 Barbatre (1480): Tucoo-Chala/Pinzuti, “Le voyage” (n. 12), p. 145

66 Guylforde (1506): Ellis, The Pylgrymage (n. 18), p. 37.

67 Anselm of Cracow (1508): Thesaurus monumentorum sive lectiones antiquae, Jacques Basnage ed., Amsterdam 1725, vol. IV, pp. 776-794, p. 779: "In parti meridionali dictae navis Ecclesia habet tredecim fenestras, in Aquilonari undecim, et hae fenestrae in altum habent, ut puto, quinque cubitos vel circa, in latum duos vel circa, glebatae cemento et obfuscatae, ne appareat eius pulchritudo vel aurum, quod adhuc in parietibus alicubi apparet non abrasum per Sarracenos". Cf. Farnad, Compendiosa description (n. 19), f. 19r, about the decaying mosaics in the Nativity cave: "Et si optas scire figuram capelle sancte huius vide in tabula cuius testudo cum sanctuario eius est opere musaico facta, scilicet de vitro deaurato picturato, sed in nonnullis locis per infideles est dirutum".

68 Josue von Beroldigen, Pilgerfahrt zu dem Heiligen Lande 1518, Odo Lang ed., Einsiedeln 2008, p. 107.

69 Fadrique Enríquez de Ribera, Viaje a Jerusalén, in Paisajes de la Tierra Prometida. El Viaje a Jerusalén de Don Fadrique Enríquez de Ribera, Pedro García Martín [et al.] eds, Madrid 2001, pp. 248-249. 
to either Christ's birth or the Final Judgement, as they could read in the text of Burchardus of Mount Zion ${ }^{70}$. In general, the very fact that iconographic descriptions in this period tended to be much more imprecise than in previous times may indirectly indicate that the conditions of visibility had become harder: as the Franciscan Luigi Vulcano put it, visitors were aware that a very wide program of sacred images was displayed there, but "because of their antiquity they can hardly be inspected" ${ }^{\prime 71}$. Moreover, Western pilgrims tended to spend less time in the upper church. Their visit was namely guided by the local Franciscans and organized in a ritualized way: with a lit candle in their hands, they accessed the grottoes of Saint Jerome from the convent and entered the Nativity cave from the grotto of the Innocents through a door which had been open in the 1470s. The original stops at the altar of Christ's circumcision in the south transept and at that of the Magi on the opposite side were gradually abandoned, presumably for the sake of avoiding any nuisance from the Turks or from the rival Christian communities $^{72}$. It was now possible for visitors to see the underground holy sites even without entering the Nativity church and therefore the latter's ornaments could be either ignored or simply glanced at. Nonetheless, the combination of white, polished marbles with gold and blue mosaics was still praised by some more attentive visitors as the most luxurious church decorum on earth, whose light effects could only be paralleled with those produced by mirrors ${ }^{73}$.

The Portuguese Franciscan Pantaleão d'Aveyro, writing in 1569, was much impressed by the "curiosidade" of the old building. He praised the wonderful chromatic effects created by the polished marble pavement, reflecting the multiple colours of the mosaics in the nave, and was able to understand the meaning of the painted program. He observed that the columns were decorated with figures of apostles, prophets and patriarchs, recognized Old and New Testament scenes in the mosaics, and identified the councils with visual evocations of the old patriarchal sees of Antioch, Constantinople, Alexandria, and Jerusalem. He found, anyway, that the Tree of Jesse was the most impressive composition, including figures of monumental dimensions which could be viewed as an outstanding work of art. Finally, he observed that the walls of the main apse and the transepts were still reveted with rich mosaics and marble plaques of the same type used in the nave ${ }^{74}$.

In the following decades the Basilica suffered from a gradual decay. In the late sixteenth century the nave was appropriated by the Turks and reserved for Muslim devotions to the holy site ${ }^{75}$. Moreover, the space was also used as the place where the qadi of Bethlehem administered justice and even resided with his family. The knight Jean Zuallart, in 1586, describes him sitting on a carpet laid on the flight-of-steps leading to the choir, by then the only part of the building used for the performance of liturgical rites exclusively by the Greek Orthodox and only on the occasion of some major feasts. According to this author, the appropriation of some parts of the nearby constructions by local Muslims would have encouraged the Friars to reduce the size of the main entrance, in order to prevent people from entering the church with their animals ${ }^{76}$. The very fact that, in the same period, the Franciscans decided to bolt the side door leading from the nave to their convent "to guard the place from the Arabs" indicates that the church space to the west of the choir screen was easily accessible and almost abandoned ${ }^{77}$. It is therefore no surprise that the marbles of the nave floor happened to be mostly removed in the same years: according to some authors, they were used to refurbish the ornaments of the Dome of the Rock in Jerusalem, which were actually restored on the initiative of Suleiman the Magnificent sometimes between the $1540 \mathrm{os}$ and $156 \mathrm{os}^{78}$. Already in 1563 , only the choir was still decorated with marble, whereas the nave had been provided with a new reddish pavement made of cocciopesto (lime mortar with crushed bricks $)^{79}$. Shortly later, a Swiss pilgrim reported that the main altar was completely destroyed ${ }^{80}$.

Several authors witnessed that Turkish soldiers were accustomed to strip the roof of its lead revetment to make munitions for their harquebuses, which they not infrequently used to shoot the mosaics ${ }^{81}$. The Spanish pilgrim Blas de Bluysa gives the following description of the images, as they looked in 1615: 
"From the upper cornice of the columns up to the roof [the church] is thoroughly embellished with outmost beautiful mosaics. The main chapel and the side ones are decorated with stories of the Old and New Testament, whereas in the body of the church are represented the seven patriarchal churches. And the walls between the windows, which are located at convenient distance from each other, are decorated with angels: even such paintings are mostly broken and consumed, because of both their antiquity and the ill-treatment which was and is daily made to them by the Turks with their harquebuses, with the only exception of the images of Our Lady, whom they treat with utmost respect" ${ }^{\prime 2}$.

Yet, apart from such deliberate attacks, the mosaics were also said to be suffering from gradual deterioration. Those in the upper church looked consumed and decaying to the Dutch pilgrim Kootwijk in $1619^{83}$, whereas those in the vault of the Nativity cave were mostly vanished or strongly darkened by the smoke of the lamps already by the end of the sixteenth century ${ }^{84}$. Seventeenth century visitors were extremely disappointed by the deserted appearance of the building:“The church is left for the most part desolate", wrote George Sandys in 1615 , "the altar naked, no lamps maintained, no service celebrated, except at times extraordinary" ${ }^{\prime 25}$.

Probably this state of decay encouraged the Franciscan scholar Francesco Quaresmi, in 1626, to work out an accurate record of the extant mosaics and a systematic transcription of the Greek and Latin inscriptions scattered throughout the building, with the only exception of those displayed in the column paintings. He was the first to describe all the compositions decorating the choir and transepts and to correctly identify and comment on the representations of the councils in the nave ${ }^{86}$. Prior to him, only the sixteenth century Greek proskynetaria had hinted at the ecumenical, yet not at the provincial councils ${ }^{87}$. It may be, anyway, that Quaresmi focused solely on the images which bore inscriptions and whose iconography was still recognizable and that he avoided mentioning those themes which could be interpreted as arguments to support Greek claims for hegemony in the church: he did not hint, e.g., at the portrait of Manuel Comnenus, which was still noticed, in the wall opposite to the dedicatory inscription, by Don Aquilante della Rocchetta in 1598. The same author laid emphasis on the importance of the bilingual texts, which could be interpreted as witness to the unity of the Greek and Latin Church in the early centuries $^{88}$.

Quaresmi was also the first to formulate new thoughts about the architectural history of the building: he questioned the traditional identification of Saint Helena as the founder of the Basilica and, on the authority of Eusebius of Caesarea, came to the conclusion that the upper church was erected by Constantine over the Nativity cave, which had already been arranged as a Christian space by his pious mother ${ }^{89}$. On the contrary, he did not express himself about the date of the mosaics, usually thought to date back to Constantinian times, but his incorrect translation of the Greek dedicatory inscription in the apse bore the year 677 and therefore implied that the decoration was made in a rather old period ${ }^{90}$. In 1693 a new reading of the date as 1076 was proposed by Giovanni Ciampini,

70 Barthélemy de Salignac, Itinerarium Sacrae Scripturae, Magdeburg 1593, chap. 56, n. p., and Antoine Regnault (1549), Discours du voyage d'Outremer au Saint-Sepulchre de Jerusalem et autres lieux de la Terre Sainte, Lyon 1573, pp. 129-130 (program ending with the Nativity); Ludwig Tschudi (1519), Reyss und Bilgerfahrt zum Heyligen Grab dess edlen und Gestrengen Herren Ludwigen Tschudi von Glarus, Herren $z u$ Greplong etc. Ritter, Melchior Tschudi ed., St. Gallen 1606, p. 275 (program ending with the Final Judgement).

71 Vulcano, Vera et nuova descrittione (n. 41), f. $79 \mathrm{v}$.

72 This is the interpretation usually given by Franciscan historians: cf. Augusto Facchini, Le processioni praticate dai Frati Minori nei santuari di Terra Santa. Studio storico-liturgico, Cairo 1986, pp.39-56.

73 Tschudi, Reyss (n. 70), pp. 274-275.

74 D'Aveyro, Itinerario (n. 14), f. 149r-150v

75 Jacques de Villamont, Les voyages du seigneur de Villamont, Rouen 1610, p. 449.

76 Zuallart, Il devotissimo viaggio (n. 21), pp. 206-208. Cf. Amico, Trattato (n. 21), p. 5

77 Amico, Trattato (n.21), p. 5.

78 Ibidem, p.5; Henry de Beauvau, Relation journalière du voyage $d u$ Levant, Nancy 1619, p.145. On the restorations in the Dome of the Rock, cf. Oleg Grabar, The Dome of the Rock, London 2006, pp. 189-200.

79 Vulcano, Vera et nuova descrittione (n. 41), f. 79r; Quaresmi, Historica, theologica et moralis (n. 54), p. 642, 643.

80 Sebastian Werro, Itinerarium Hierosolymitanum (1581), Fribourg, Bibliothèque cantonale et universitaire, Ms. L 181, fol. 64v.

81 Amico, Trattato (n. 21), p. 8 .

82 de Buysa, Relación nueva (n. 54), pp. 24v-25r. Cf. also Giovanni Francesco Alcarotti, Del viaggio di Terra Santa, Novara 1596, p. 149.

83 Jan Kootwijk (Cotovicus), Itinerarium Hierosolymitanum et Syriacum, Antwerp 1619, p. 228

84 Zuallart, Il devotissimo viaggio (n. 21), p. 209.

85 George Sandys, Sandys Travels, London 1673, p. 139.

86 Quaresmi, Historica, theologica et moralis (n. 54), vol. II, po. 645-673.

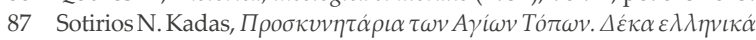

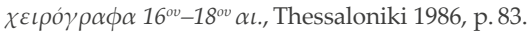

88 Aquilante della Rocchetta, Peregrinatione di Terra Santa e d'altre provincie, Palermo 1630, p. 259: "Il sopradetto Emanuele era imperatore di Costantinopoli, onde v'era anco la sua imagine lavorata di mosaico all'altra parte di rimpetto di queste lettere".

89 Quaresmi, Historica, theologica et moralis (n. 54), vol. II, pp. 673-675.

90 Ibidem, p. 672. 
whose description of the mosaics relied directly on Quaresmi's work and was instrumental to enrich his historical survey of the sacred buildings erected by Constantine in various centres of the Roman Empire. His major merit was to publish an engraving, sent to him by the Bethlehem Franciscans, showing the mosaic decoration of the north wall of the nave, which in that period was still almost thoroughly preserved ${ }^{91}$.

It may be that such an emphasis on Constantine's and Helena's patronage was instrumental to support the Custody's claims on the building: the hint at early Christianity enabled the Friars to stress the connection with Saint Jerome, the Latin father who had spent most of his time in Bethlehem and was said to be the founder of the Franciscan convent. This view was traditionally shared also by the Greek Orthodox ${ }^{92}$, but in the late seventeenth century it was nuanced by the Greek Patriarch Dositheos, according to which the church building was basically the outcome of a reconstruction made on the initiative of Justinian in the sixth century ${ }^{93}$. A recent study has proposed to read this assertion as a rhetorical argument to back Greek claims on the Bethlehem holy sites in an anti-Latin perspective ${ }^{94}$. It must be stressed, anyway, that the attribution to Justinian was first proposed in 1674 by a Catholic author, the French Jesuit Michel Nau, who quoted the only old text hinting at the involvement of the Byzantine Emperor, a passage in Patriarch Eutychius of Alexandria's Annals, dating from ca 933-940. As to the date of the mosaic decoration, both Nau and Patriarch Dositheos relied on the evidence provided by the dedicatory inscription, yet came to different conclusions: they agreed that they were made in the twelfth century, but they attributed the patronage of the program to either Manuel Comnenus or Amalric I of Jerusalem ${ }^{95}$.

Meanwhile, the church underwent extensive restorations. After years of negotiations with the Sublime Porte, Patriarch Dositheos was finally allowed to make repairs to the roof: thanks to the sponsorship of a rich Greek devotee, Manolakis of Kastoria, who was rumored to have spent the enormous sum of one hundred thousand gold scudi, it was possible not only to renovate the roof with new beams from Mytilene and a new lead covering, but also to make new ornaments in the church. The windows, which had been previously closed with hard stones, were substituted with iron castings and glass; some of the nave walls were plastered, and the side entrances to the Nativity grotto were embellished with new marble slabs. Moreover, carvers and painters from Chios were entrusted to erect an iconostasis in the altar space ${ }^{96}$. It was probably in this period that the choir underwent substantial changes. Until then the area was bounded by a low chancel extending also to the side aisles and provided with five entrances, as shown in Bernardino Amico's engraving and in the map published by Beauveau in $1615^{97}$. This structure was substituted with a high wall rising up to the height of the columns, whereas the passageways between the side aisles and the transepts were blocked. Access was granted by three doors, which could be locked at night ${ }^{98}$. Meanwhile, the niche of the Nativity had been deprived of the Italian painting displaying Mary and Joseph adoring the Child, so that the medieval mosaic was made again accessible to viewers ${ }^{99}$.

Later descriptions indicate that the building and its decoration kept deteriorating. At the end of the seventeenth century, the mosaics were said to be mostly defaced ${ }^{100}$. When the Franciscans were restituted their rights in 1690, they were reported to have made some significant alterations to the church decorum, including the removal of the iconostasis (restored by the Greeks in 1764) and the making, in 1717, of a new star-shaped silver revetment, bearing the inscription Hic de Virgine Maria Iesus Christus natus est, for the hole of Christ's birth $^{101}$. An accurate description of the present state of the church was given in 1767 by Giovanni Mariti: the sixteenth-century cocciopesto pavement was still there, the marble revetments had completely disappeared, whereas the mosaics were still largely preserved, albeit in bad conditions. Some remnants of the Tree of Jesse were still visible, whereas the compositions on the north and south walls of the central nave were fairly well preserved. On the contrary, the mosaic in the central apse had disappeared, but one could still discern the Annunciation on the triumphal arch. Mariti was able to see the Pentecost, the Ascension and the Incredulity of Thomas on the northern side and the Adoration of 
the Magi, Christ and the Samaritan Woman, the Arrest of Jesus and the Burial of Christ to the south. Strangely enough, he omitted the Transfiguration and the Entry into Jerusalem, still preserved even nowadays. He was also the first Western visitor to correctly read the date of the dedicatory inscription as 1169 and to criticize both Quaresmi's transcription and Nau's interpretation of the same date as given according to the Hegira. Finally, he lamented that the Latin inscriptions were much worse preserved than the Greek ones and accused the Greek Orthodox clergy, who had regained hegemony on the church in 1757, of intentionally neglecting them ${ }^{102}$.

The last remnants of mosaics seem to have quickly deteriorated in the decades following Mariti's visit. In the early nineteenth century visitors remarked that only some compositions were still visible in the nave and were mostly destroyed ${ }^{103}$ The earthquake of May $26^{\text {th }}$, 1834 , must have caused some of the extant fragments to fall down, even if no hint at it is encountered in the contemporary report by the Cypriot monk Neophytos, who wrote that the church, unlike the nearby monasteries and the belfries, was not seriously damaged ${ }^{104}$. As the seism took place in the aftermath of the first Egyptian-Ottoman war (1831-1833), when the region was under the control of Muhammad Ali, the three communities made pressures on both the Khedive and the Sultan to obtain the right to make restorations in the church. Already by 1837 the Greek Orthodox had collected a large amount of money through donations of believers ${ }^{105}$, and in 1842 , after the final reestablishment of Ottoman rule, they were granted exclusive permission to repair it. The works were described in this way by Neophytos:

"As soon as we received permission, we immediately began the work in about the middle of May and until the end of November of that year the whole floor of that church was reveted. The walls located between the eastern wall of the Holy Bema up to the external door were whitewashed. We also removed those mosaic tesserae which had got spoilt because of their old age. The windows were provided with irons and glass, and all lead plaques of the roof were removed and substituted with more solid ones. In short: this church was embellished in its upper and lower, interior and exterior parts, in such a way that it looked like a most pleasant Paradise" ${ }^{106}$.
The feelings of the other two communities were much less enthusiastic, but their protests did not concern the fate of the mosaics. The Armenians claimed that the Greek Orthodox had altered the sacred space in order to appropriate the parts belonging to them. The Franciscans appealed to the Sultan to denounce the construction of a stairway on the south apse and of two steps on the north and south side of the elevated choir, and made all possible efforts to avoid the removal of some marble plaques in the Nativity cave, said to date from Constantine's times ${ }^{107}$. The Friars also accused the Greeks of deleting the historical traces of Latin presence in Bethlehem: some mosaic inscriptions in the Incredulity of Thomas and the Ascension

91 Giovanni Ciampini, De sacris aedificiis a Constantino magno constructis synopsis historica, Rome 1693, pp. 150-162.

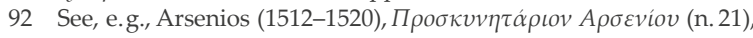
pp. 480-485.

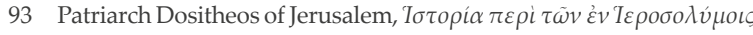
$\tau \alpha \tau \rho \iota \alpha \rho \chi v \sigma \sigma \alpha v \tau \omega v$, Bucharest 1715, p. 1213.

94 Jordan Pickett, "Patronage Contested: Archaeology and the Early Modern Struggle for Possession at the Church of the Nativity, Bethlehem",in Visual Constructs of Jerusalem, Bianca Kühnel, Galit Noga-Banai, Hanna Vorholt eds, Turnhout 2014, pp. 35-44, sp.pp. 36-38.

95 Michel Nau, Voyage nouveau de la Terre-Sainte [1676], Paris 1757, pp. 400-401.

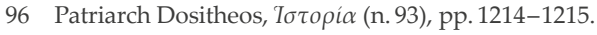

97 Amico, Trattato (n. 21), pls 4-5; Beauvau, Relation journalière (n. 78), p. 145. Cf. also Mariano Morone da Maleo, Terra Santa nuovamente illustrata, Piacenza 1669, p. 265, who describes the chancel as a "mezo muro".

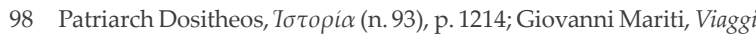
per l'isola di Cipro e per la Soría e la Palestina, Florence 1770, pp. 55-56.

99 As noticed by Francesco Caccia, Compendium, sive brevis Relatio locorum sanctorum quae Seraphicus Ordo Franciscanorum ultra quadringentos annos legitime possedit et a Schismaticis per aliquos annos iniuste et dolose ablata nunc iterum maiori gloria nobis per Decretum magni Sultani anno 1690 die 26 Junii sunt restituta, Wien 1693, p. 27.

100 Ibidem, p. 26.

101 Bagatti, Gli antichi edifici (n. 19), p. 125 n. 44; R. W. Hamilton, The Church of the Nativity, Bethlehem. A Guide, Jerusalem 1947, p. 83.

102 Mariti, Viaggi (n. 98), pp. 55-56.

103 Daniel Wegelin, Erinnerungen aus Russland und dem Orient, Zurich 1845, vol. I, p. 120; Giovanni Failoni, Viaggio in Siria e nella Terra Santa, Verona 1833, p. 118

104 Neophytos Agiotaphitis, Twenty years, 1821-1841, being a continuation of the history of the Holy Orthodox Church subject to the throne of Jerusalem, S. N. Spyridon ed., "Annals of Palestine, 1821-1841", Journal of the Palestine Oriental Society, XVIII (1938), pp.63-96, sp. pp. 92-93. Damages to the Franciscan monastery are mentioned also by Amiran/ Arieh/Turcotte, “Earthquakes” (n. 45), pp. 272-273.

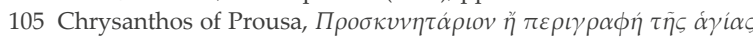

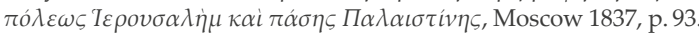

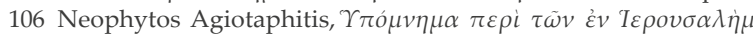

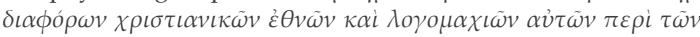

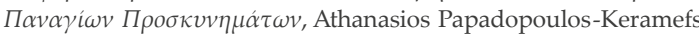

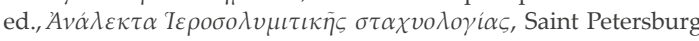
1897, vol. III, pp.411-456, sp.p. 441. Cf. also V. Ioannides, $H$ d $\gamma i \alpha$

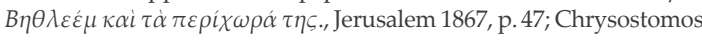

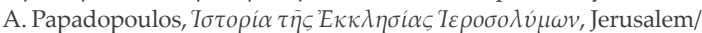
Alexandria 1910, pp. 688-690.

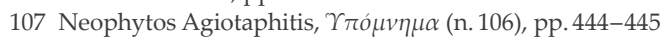




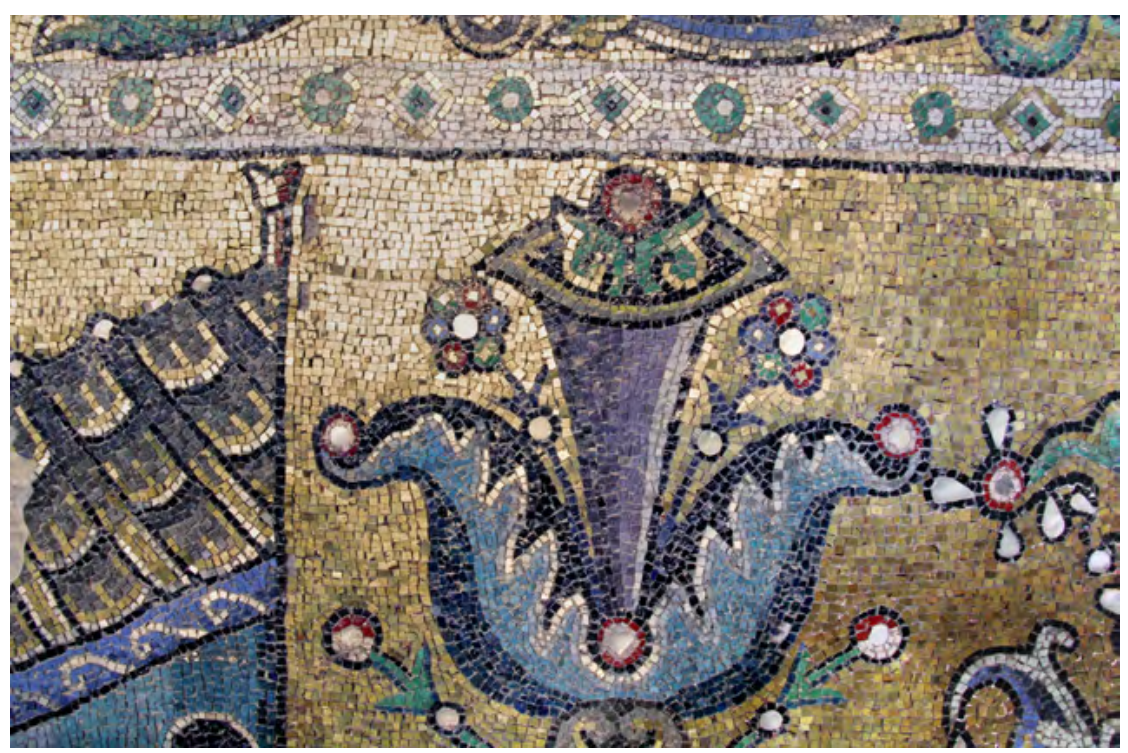

on the north transept were said to have disappeared on the occasion of the 1842 restorations ${ }^{108}$. The repairs made to the roof proved not to be very efficacious, given that they could not thoroughly prevent rain from falling inside the church ${ }^{109}$.

The church refurbished and reshaped in 1842 is the one which has been transmitted to our days with only minor changes, such as the demolition of the choir screen in $1919^{110}$. The promulgation of the status quo in 1852 , which prevented all of the three communities from making any new restorations in the absence of a mutual agreement, froze the building in the state of repair it had received in the mid-nineteenth century. It is worth stressing that the Nativity church started being investigated from an archaeological and art historical viewpoint only from this period onwards. The key-figure in this process can be considered to be the diplomat and archaeologist Marquis Melchior de Vogüé, who had a good first-hand knowledge of Palestine and was directly involved, after he was appointed French ambassador in Constantinople, in the disputes arising in 1873 about the Franciscan request to redecorate the Nativity cave with an asbestos covering, embellished with images ${ }^{111}$. His book Les églises de la Terre Sainte, published in 1860, included the first accurate description and historical analysis of the building and its monumental decorations.

Concerning the question whether the present erected by Constantine in the fourth century or as a reconstruction made on the initiative of Justinian in the sixth century, he considered that the first option was largely much more probable, on account of the analogies with other Early Christian basilicas, the unreliability of Patriarch Eutychius' text, and the lack of any hints at Bethlehem in Procopius' narrative about the buildings erected by Justinian ${ }^{112}$. This view prevailed until the $1930 \mathrm{~s}^{113}$, when the archaeological excavations in the north transept, nave, and atrium of the basilica occasioned by William Harvey's structural survey of the building lead to the discovery of extensive portions of a fifth-century mosaic floor and the remains of an older church, whose east end included an octagonal structure ${ }^{114}$. Further data were provided by the excavations made by the Franciscans between 1948 and $1951^{115}$. Since then, scholars have interpreted the present building as either dating entirely from Justinian's times or being the outcome of two different construction phases ${ }^{116}$. Very recently, it has been proposed that the triconch-shaped eastern end may have been erected in Crusader times ${ }^{117}$.

The analysis of the extant mosaic fragments was often hampered by their precarious state of preservation. Shortly after the 1842 restoration, Titus Tobler, who wrote a monographic work on Bethlehem's topography, was just able to distinguish some indistinct figures and admitted his inability to identify their subjects ${ }^{118}$. Marquis de 


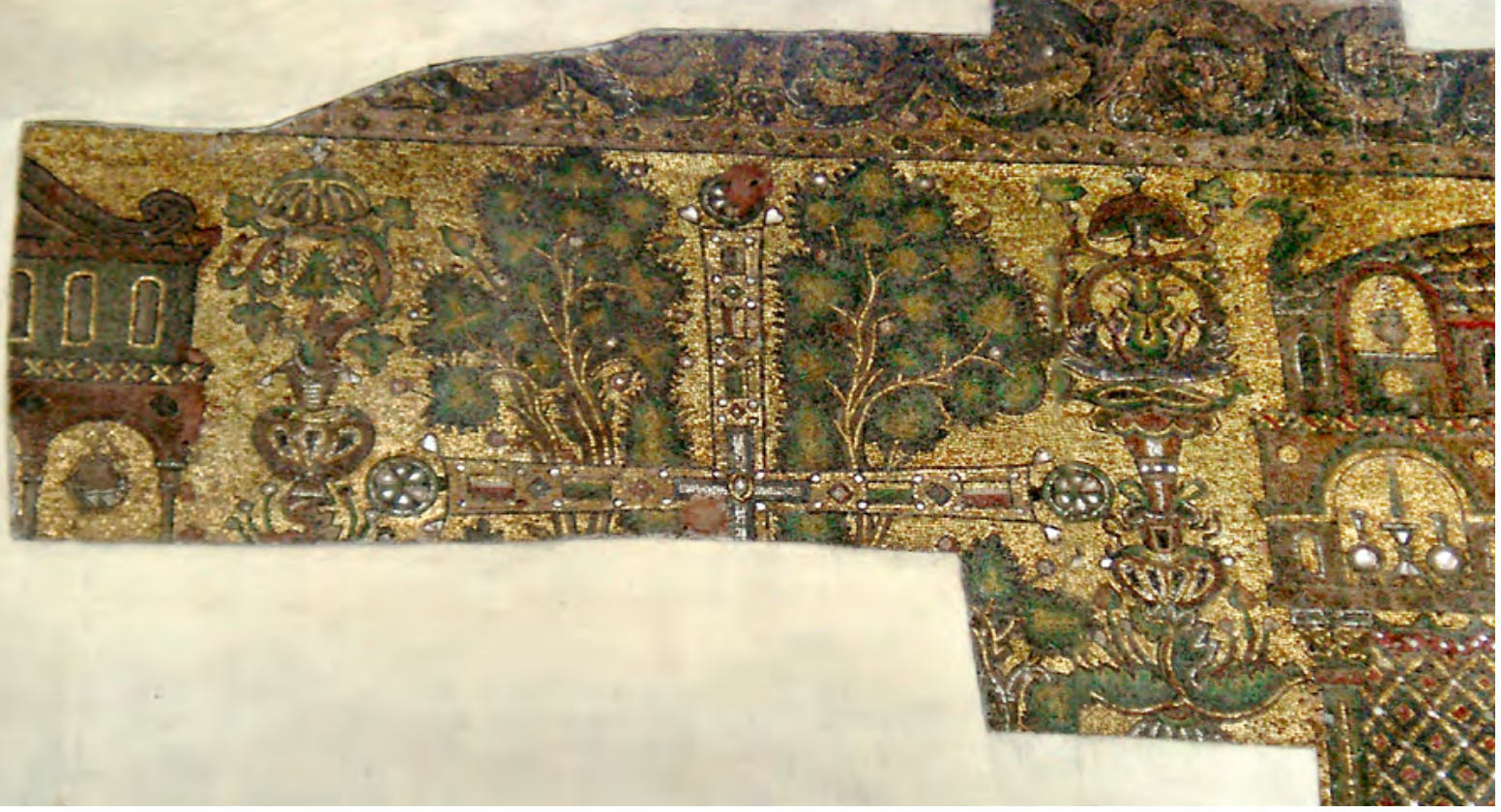

Vogüé relied on Quaresmi's and other authors' descriptions to provide an accurate report on the remains of the medieval decoration. Eye-inspection enabled him to sense that the program stood out for its mixed character, combining essentially Byzantine visual conventions with a number of Western elements. He came then to the conclusion that this stylistic mélange was the direct outcome of the specific circumstances in which the church had been decorated in 1169, namely on the initiative of the Crusader king but with the involvement of the Greek painter Ephrem mentioned in the dedicatory inscription ${ }^{119}$. In 1911, at the age of 82, de Vogüé visited Bethlehem for the second time and found that the mosaics had become much darker than in his previous visit made fifty-eight years earlier, in 1853 . Nonetheless, he was able to notice the signature "BASILIUS PICTOR" displayed close to the lower edge of one of the angels on the north wall of the nave and proposed that this second painter may have been a collaborator who materially carried out the mosaic compositions designed by Ephrem ${ }^{120}$.

108 Francesco Cassini da Perinaldo, La Terra Santa descritta, Genoa 1855 p. 167; Melchior de Vogüé, Les églises de la Terre Sainte, Paris 1860, p. 96 109 Cf. Tobler, Bethlehem in Palästina (n. 50), p. 85.

110 Cust, The Status Quo (n. 1), p.39.

111 Vincent/Abel, Bethléem (n. 9), pp. 204-205

112 de Vogüé, Les églises (n. 108), pp. 46-64.

113 Constantinian origins were argued by William R. Lethaby, "A General Historical and Descriptive Account", in The Church of the Nativity at Bethlehem, William Harvey [et al.] eds, London 1910, pp. 13-30, and Edmund Weigand, Die Geburtskirche von Bethlehem. Eine Untersuchung zur christlichen Antike, Leipzig 1911. The theory of mixed
Constantinian and Justinianic phases was most notably upheld by Vincent/Abel, Bethléem (n. 9), pp. 19-106.

114 Robert W. Hamilton, "Excavations in the Atrium of the Church of the Nativity", Quarterly of the Department of Antiquities in Palestine, III (1934), p. 1-8; William Harvey, Structural Survey of the Church of the Nativity, Bethlehem, London 1935; Idem, "The Early Basilica at Bethlehem", Palestine Exploration Quarterly Found, LXVIII (1936), pp. 28-33; E. T. Richmond, "Basilica of the Nativity. Discovery of the Remains of an Earlier Church", Quarterly of the Department of Antiquities in Palestine, v (1936), pp. 75-81 and vi (1937), pp. 63-72; Louis-Hugues Vincent, “Bethléem. Le Sanctuaire de la Nativité d'après les fouilles récentes", Revue biblique, XLV (1936), pp. 418-459; William Harvey, "Recent Discoveries at the Church of the Nativity, Bethlehem", Archaeologia, LXXXVII (1937), pp.7-17; Adolf Rücker, "Bericht über die archäologischen Ergebnisse und Untersuchungen in der Geburtskirche in Bethlehem", Oriens christianus, XIII (1938-1939), pp. 224-238. For the dating of the mosaic floor in the fifth century see Ernst Kitzinger, "The Threshold of the Holy Shrine. Observations on Floor Mosaics at Antioch and Bethlehem", in Kyriakon. Festschrift Johannes Quasten, Münster 1970, vol. II, pp. 639-647; Rina Talgam, Mosaics of Faith. Floors of Pagans, Jews, Samaritans, Christians, and Muslims in the Holy Land, Jerusalem 2014, pp. 383-405.

115 Bagatti, Gli antichi edifici (n. 19), pp. 16-54; Idem, L'Église de la gentilité en Palestine ( $I^{\text {er }}-\mathrm{XI}^{e}$ siècle), Jerusalem 1968, pp. 715-720; Idem, "Recenti scavi a Betlemme", Liber Annuus, XVIII (1968), pp. 180-237.

116 Mamert Vionnet, "Les églises de la Nativité à Bethléem”, Byzantion XIII (1938), pp. 91-128; Robert W. Hamilton, The Church of the Nativity, Bethlehem. A Guide, Jerusalem 1947; Richard Krautheimer, Early Christian and Byzantine Architecture, $4^{\text {th }}$ edition revised by Richard Krautheimer and Slobodan Čurčić, New Haven 1986, p. 266; Yoram Tsafrir, "The Development of Ecclesiastical Architecture in Palestine", in Ancient Churches Revealed, Yoram Tsafrir ed., Jerusalem 1993, pp.1-16, sp.pp. 8-10. Alternative datations were proposed by Alfons Maria Schneider, "Zur Baugeschichte der Geburtskirche in Bethlehem", Zeitschrift des deutschen Palästina-Vereins, LXIV (1941), pp. 74-91 (early sixth century); Beat Brenk, Spätantike und frühes Christentum, Frankfurt/Berlin/Wien 1977, pp. 193, 195 (early sixth century); and Marcell Restle, "Bethlehem", Reallexikon zur byzantinischen Kunst, Stuttgart 1966, vol. I, pp. 599-612 (late sixth century). Cf. also Gustav Kühnel, "Betlemme”, in Enciclopedia dell'arte medievale, Rome 1991-2002, vol. III, pp. 463-468; L.A. Beljaev, N. N. Lisovoj, “Вифлеем”, in Православная энцчиклопедия, Moscow 2004, vol. VIII, pp. 597-603.

117 Pickett, “Patronage Contested" (n. 94), pp. 41-44

118 Tobler, Bethlehem in Palästina (n. 50), p. 84

119 de Vogüé, Les églises (n. 108), pp. 64-106.

120 Idem, Jérusalem hier et aujourd'hui. Notes de voyage, Paris 1912, pp. 21-22.
4/ Crux gemmata, detail of the Provincial councils of Syro-Palestine, mosaic north wall of the nave, Nativity church, Bethlehem, a 1155-1169 
5/Detail of the downward-sloping tesserae in the background of an angel figure between the fourth and fifth window, north wall of the nave Bethlehem, Nativity church, ca 1155-1169

6/Vegetal scrolls, mosaic, octagonal arcade, Dome of the Rock, Jerusalem, ca 691
The two basic questions formulated by de Vogüé, namely the dating and authorship of the mosaics, and therefore the latter's cultural and artistic identity, played a role of protagonist in the scholarly debate of the following decades. In analogy with the analysis of the church architecture, the previously uncontested dating in the Crusader period was questioned, in the 1930s, by Henry Stern, who detected two different decoration phases. According to his view, whereas all the images in the transepts and the south wall of the nave were to be considered as belonging to the twelfth century campaign by Ephrem and Basilius, the provincial councils on the north wall were to be dated back to the beginnings of the eighth century, on account of their aniconic character, the stylistic analogies with the early Islamic mosaics of the Dome of the Rock in Jerusalem and the Umayyad Mosque in Damascus and some technical peculiarities, such as the use of mother-of-pearl inserts, which marked out, in his opinion, only this portion of mosaic/Fig. 3/. In his view, the rest of the decoration, including the ornamental bands and angels on the same wall, lacked the strong naturalistic effects which could be detected exclusively in the trees and fantastic plants separating the architectural frames used to evoke the towns of Antioch and Sardica ${ }^{121}$.

This view enjoyed some success, especially because it was accepted and discussed in André Grabar's authoritative book L'iconoclasme byzantin (1957) ${ }^{122}$. Yet other authors manifested their scepticism and observed that the vegetal motifs in Bethlehem, albeit generically of Islamic inspiration, were much more stylized than those in the Umayyad monuments in Jerusalem and Damascus, the most interesting comparanda being the eleventh-century mosaics in the el-Aqsa mosque $^{123}$. Anyway, it was only through the fieldwork carried out by Gustav Kühnel between 1979 and 1983 that research made an authentic leap in quality. Kühnel was given permission to take high-quality pictures of all ancient paintings in the church and even to make use of a moving scaffolding to clean, study, and photograph the mosaics in both the nave and transepts ${ }^{124}$. By removing some layers of plaster he was able to rediscover one more fragment from the ecumenical councils on the south wall and another signature by Basilius, written in Syriac and located in the same mosaic panel opposite to the Latin one. This activity enabled Kühnel to ascertain the lack of any seams between the different portions of mosaic, the employ of tesserae of the same dimensions, the chromatic coherence of the different parts and the absence of any sign of ancient restoration. Therefore he contested Stern's assumptions and came to the conclusion that the decoration was made in a single campaign which probably began in the mid-1150s and was over by 1169. The stylistic shifts between the transept and the nave, or between the latter's north and south wall, were explained as mirroring the activity of different masters within the same team ${ }^{125}$.

Kühnel's work aroused a renewed interest for the Bethlehem mosaics, especially in the 1980 s and 1990s. Scholars made efforts to re-evaluate their significance for the history of medieval craftsmen and their methods of work, of artistic and cultural interactions in the medieval Mediterranean and more specifically in Crusader Palestine. The program was alternatively read as mirroring either the King of Jerusalem's or the Byzantine Emperor's politics of Mediterranean alliances and strategies for the union of the Eastern and Western churches. The role of Bishop Raoul has also been emphasized, and associated with a specific will to enhance the role of Bethlehem as a prominent ecclesiastical site ${ }^{126}$. Recent studies have stressed the impact played by Christmas liturgy on some iconographic peculiarities, such as the presence of a Sibyl in the now lost Tree of Jesse ${ }^{127}$. It has been debated whether Ephrem can be considered to be a Byzantine or indigenous artist, whereas Basilius' identification as an Arab Christian seems to be corroborated by his signature in Syriac, the liturgical language used by different denominations in the Holy Land ${ }^{128}$. Finally, strictly connected with the identification of the artists' origins and training is the evaluation of the stylistic and compositional peculiarities of the decoration: rather than witnessing an old dating, the imitation of motifs connected with the Dome of the Rock can be regarded as a revival of forms directly associated with both visual conventions and technical practices rooted in the Palestinian context ${ }^{129}$. 

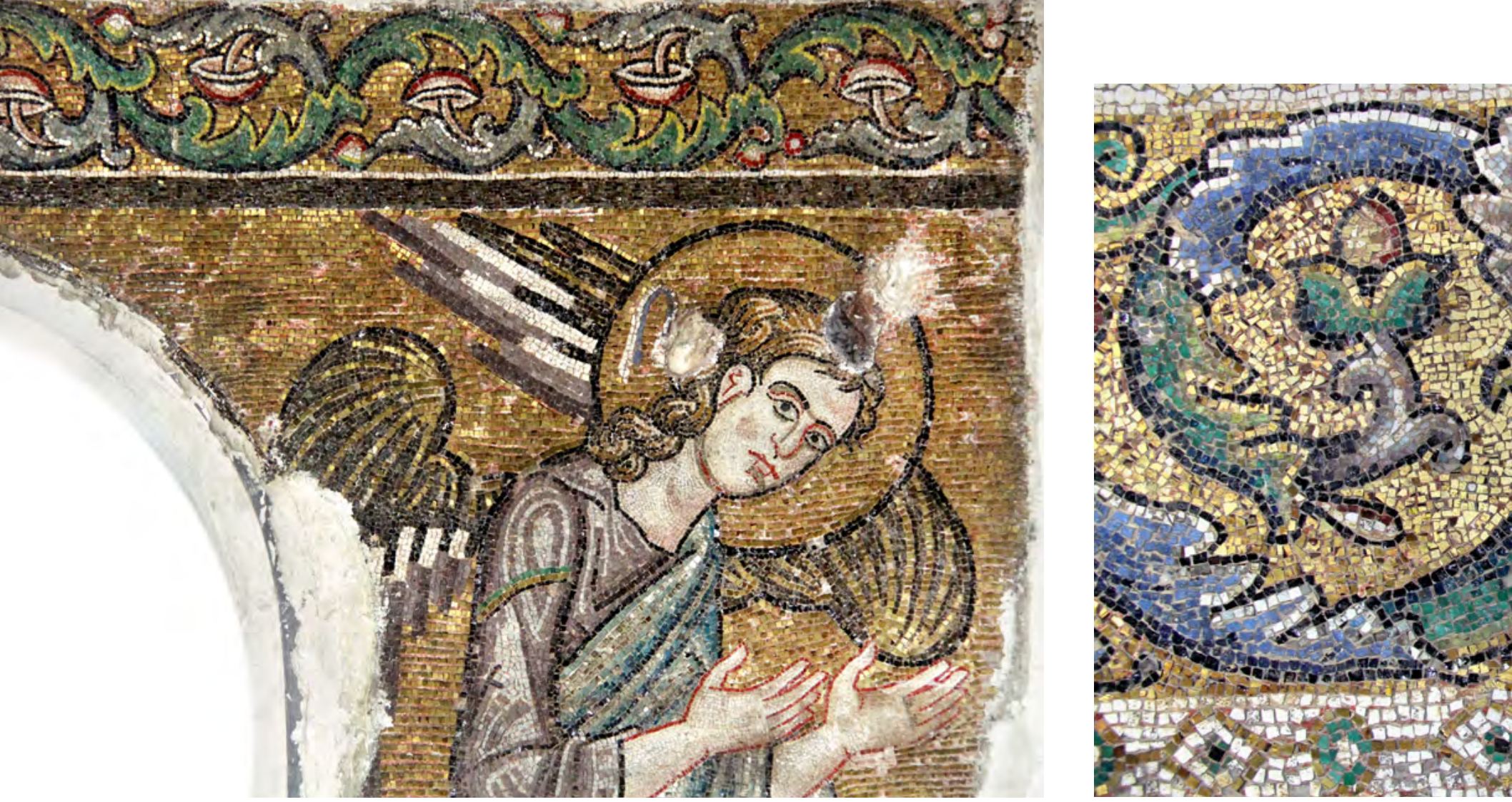

"Until it can be demonstrated what portion of the mosaics of the provincial councils were reset in the twelfth century using new materials and/or techniques along with the mosaics in the rest of the church, we are obliged to consider the possibility that, along with their design conception, they may be physically earlier, wholly or in part, dating, if Stern is correct, ca A.D. 700" ${ }^{130}$.

Some recent discoveries enable us to shed some more light on these old-debated questions. In 2010 an international team of restorers, specialists in the preservation of cultural heritage, architects, art-historians and archaeologists coordinated by Prof. Claudio Alessandri of Ferrara University, Italy, was charged by the Palestinian National Authority to carry out investigations which were meant as a first step to the restoration of the roof. This proved to be an extraordinary chance to work out a new structural survey, make different kinds of analyses and collect many new data ${ }^{131}$. The dendrochronological tests made on the wooden elements revealed that the oldest cedar lintels in the intercolumnia of the south nave can be dated to the period between 545 and 665 , which implies that the westernmost part of the church space was built in decades ${ }^{132}$. The archaeometrical analysis indicated that the building, including its eastern end, was constructed in essentially the same period, so that a late sixth century date can be assumed for the entire architectural complex ${ }^{133}$. On the same occasion, spectrophotometric analyses were made on the painted surfaces and it was made clear that some portions of tesserae were still hidden under the nineteenth-century plastering ${ }^{134}$.

The restoration of the wooden roof began in 2013 and was entrusted to the Italian company Piacenti. It was followed by a second campaign, which involved especially the thirteenth century Armenian door. The third phase, devoted to the cleaning of the twelfth century mosaics, began in winter 2015 with the involvement of specialists under the supervision of Dr. Susanna Sarmati, Rome. The works and the present author's eye-inspection of the mosaic decoration from the scaffoldings have confirmed many of Gustav Kühnel's conclusions. The dimensions of the tesserae and their chromatic palette are actually homogenous throughout the church. Stern's allegations of a technical shift between the provincial councils and the other parts are contradicted by the widespread use of similar 

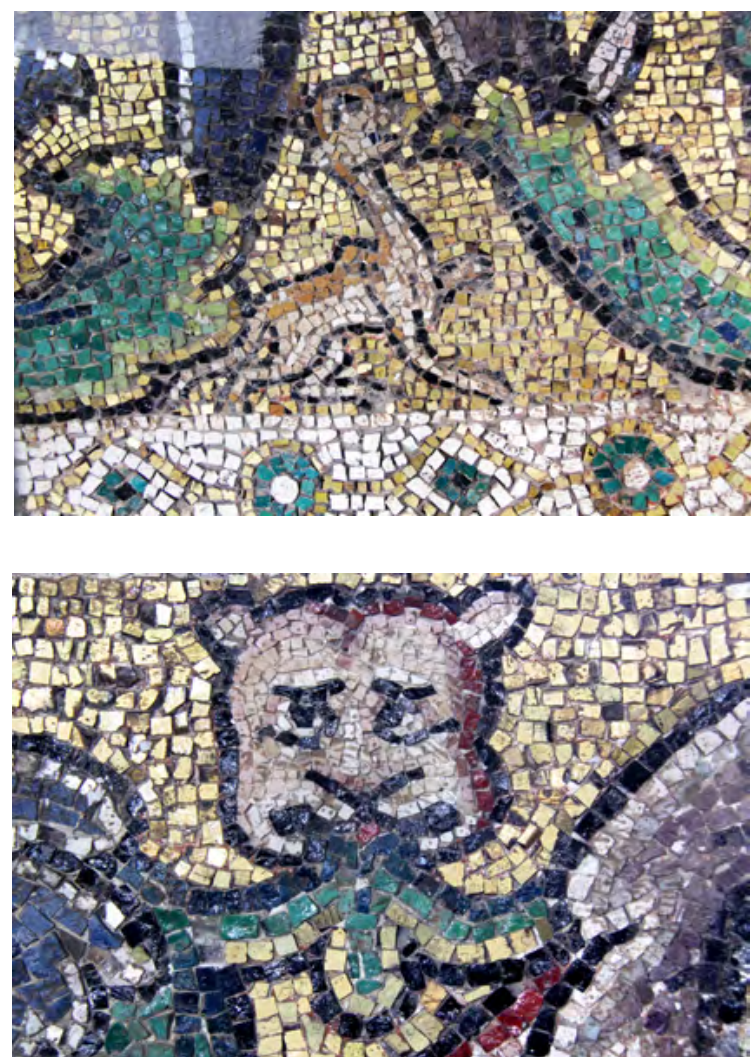
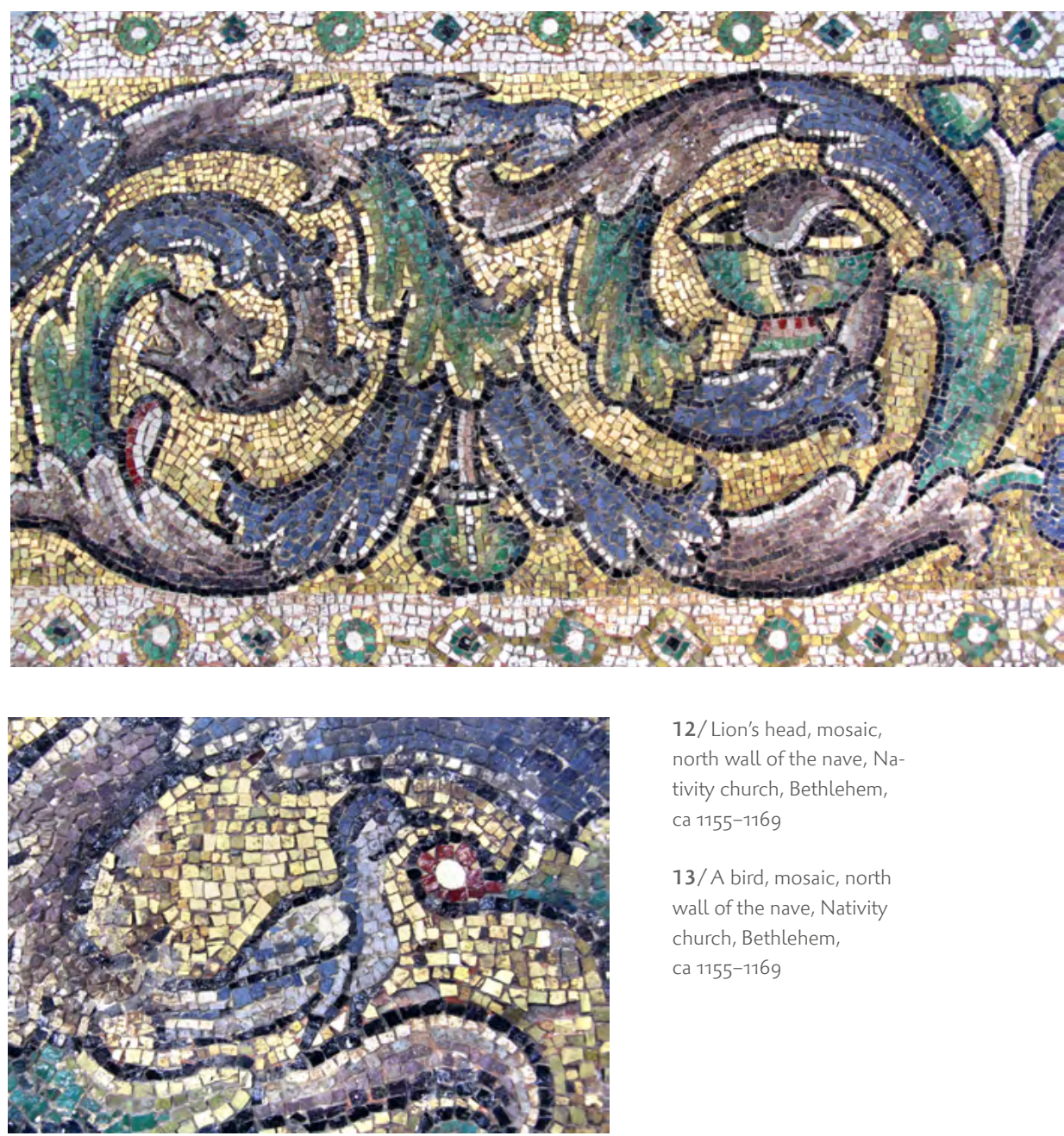

12/ Lion's head, mosaic, north wall of the nave, $\mathrm{Na}$ tivity church, Bethlehem, ca 1155-1169

13/ A bird, mosaic, north wall of the nave, Nativity church, Bethlehem, ca $1155^{-1169}$ contrary, are not only embellished with acorns, leaves, and fruits, but are also inhabited by animals, fantastic figures, and objects, including two hares, a camel, a lion's head, a bird, a chalice, a vessel, and an ampulla /Figs 8-13/. One of the spirals ends in a wolf's head with open mouth and prominent teeth /Fig. 11/. Unlike the green scrolls of the Dome of the Rock and the el-Aqsa Mosque, those at Bethlehem are composed of several multi-coloured segments, which seem to be inspired by features common in twelfth century book illumination in the Holy Land, like the painted initials of the Sacramentary of the Holy Sepulchre now divided in two parts preserved in Cambridge and Rome ${ }^{135}$.

A close examination of the mosaic surface of the trees to both sides of the crux gemmata /Fig. 14/ shows a very sophisticated use of tesserae of different chromatic tones to obtain different shades of blue, green, and yellow. From the analysis of the chemical composition of the tesserae made by Marco Verità in April 2015 with samplings from all the extant fragments it appears that the artists made use of a variety of materials, most of them belonging to types widespread between the eleventh through the thirteenth century, yet combined with other, much earlier glass tesserae, produced with techniques having disappeared by the ninth or tenth century and being typical of the Syro-Palestinian area ${ }^{136}$. Such data corroborate the dating of the whole mosaic program in the Crusader period and may indicate that artists were able to reuse materials being available in situ and, perhaps, that some of the images repeated the compositions of an earlier program of mosaic decoration, whose existence before the twelfth century is witnessed by ancient sources ${ }^{137}$.

Another significant result of the 2015 restorations is the finding of many lead balls embedded 


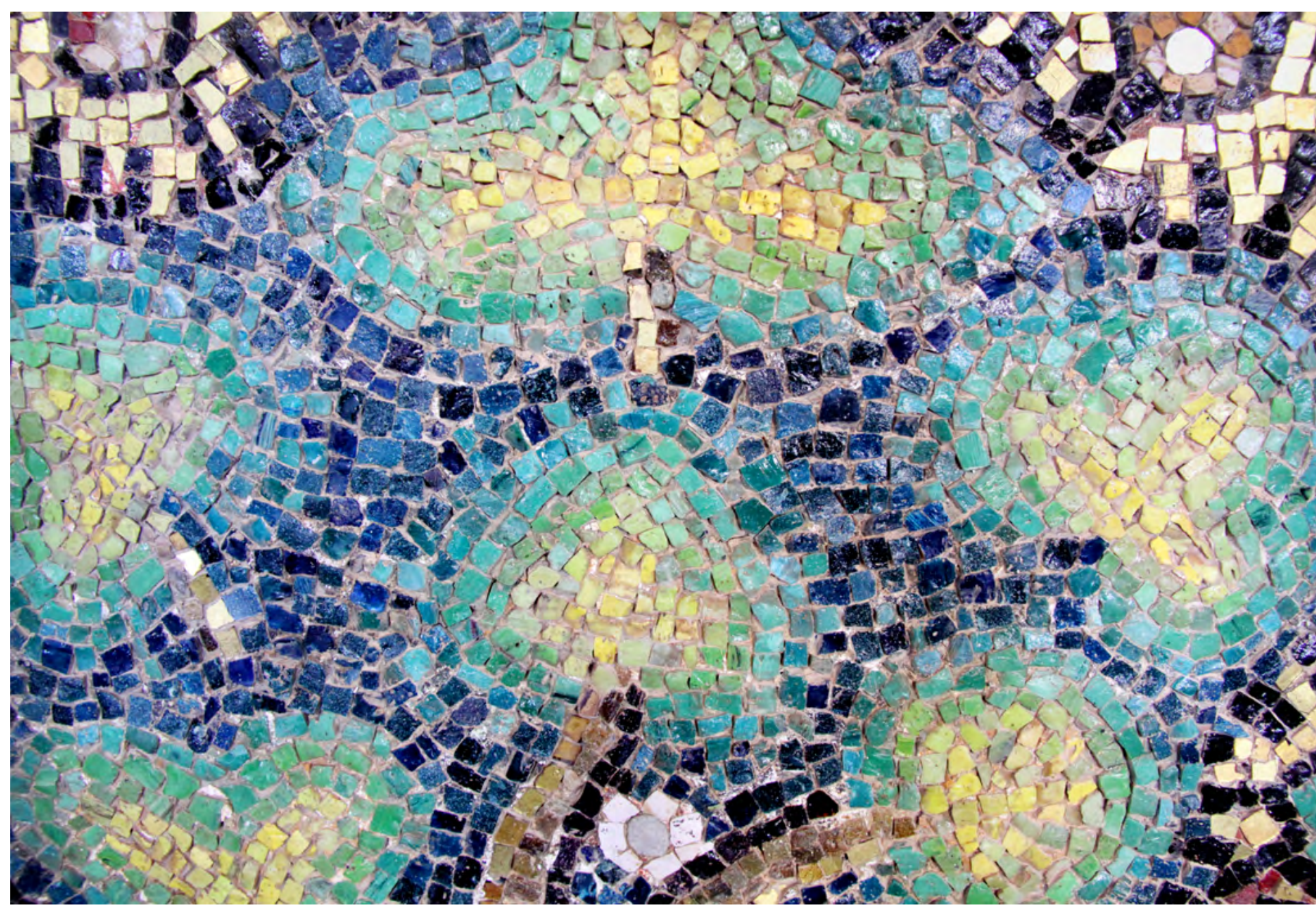

in the mosaic surface: they are evident signs of the Ottoman soldiers' harquebus shots mentioned in the late sixteenth and seventeenth centuries. The intervention also provided new evidence about the nineteenth century restoration: it was possible to verify that some portions of mosaic, especially in the marginal areas of the fragments, were hidden under the plastering, sometimes in the aim of giving a quadrangular, picture-like appearance to the images. The largest surface to be concealed was an angel figure located between the fifth and sixth window of the north wall of the nave /Fig. 15/. The image stands out for its elegant forms, being reminiscent of the so-called Comnenian classical style. It proves to be perfectly in keeping with the nearby images from both a stylistic and compositional viewpoint. The figure's dynamic attitude, emphasized by the movement of his legs, fits in with the general structure of the procession of angels, alternating more animated and more static postures. Such details as the v-shaped folds, the zigzag hems, and the knot on the border of the mantle falling down from the angel's left arm are formulas often iterated in the composition. It may be that in 1842 the fragmentary state of this figure, lacking the upper part of the head, was perceived as indecorous and unworthy of being exhibited. Its rediscovery after 173 years of neglect is a major and unexpected addition to our knowledge of medieval arts.

135 Cambridge, Fitzwilliam Museum, Ms. McClean 49, and Rome, Biblioteca Angelica, MS. D.7.3 (dating from 1128-1130). For colour reproductions and a commentary see Silvia Rozenberg, "From the Scriptoria of Jerusalem and Acre", in Knights of the Holy Land. The Crusader Kingdom of Jerusalem, Silvia Rozenberg ed., Jerusalem 1999, pp. 216-229, sp. p. 218

136 I am indebted to Dr Marco Verità for allowing me to read his report about the analyses of the glass tesserae. He is the author of a forthcoming article on the results of his research.

137 Bagatti, Gli antichi edifici (n. 19), p. 13, 58-59.
14/Branches of one of the trees to both sides of the crux gemmata mosaic, north wall of the nave, Nativity church, Bethlehem, ca 1155-1169 


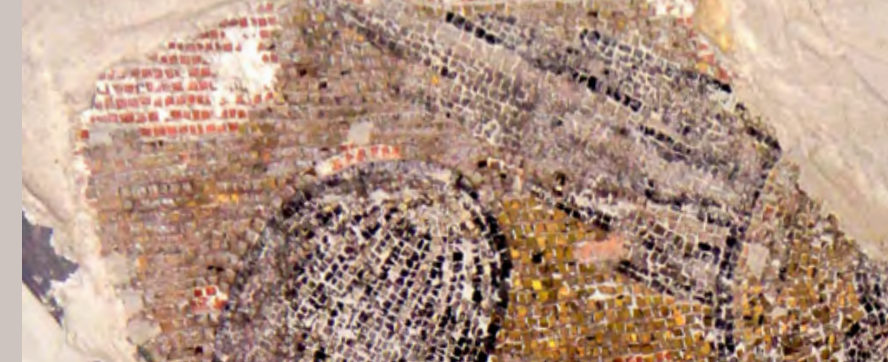

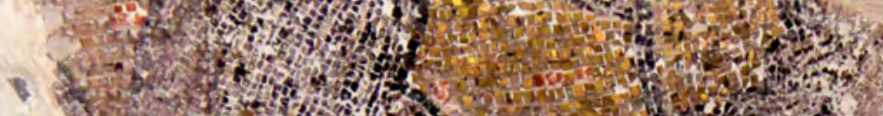

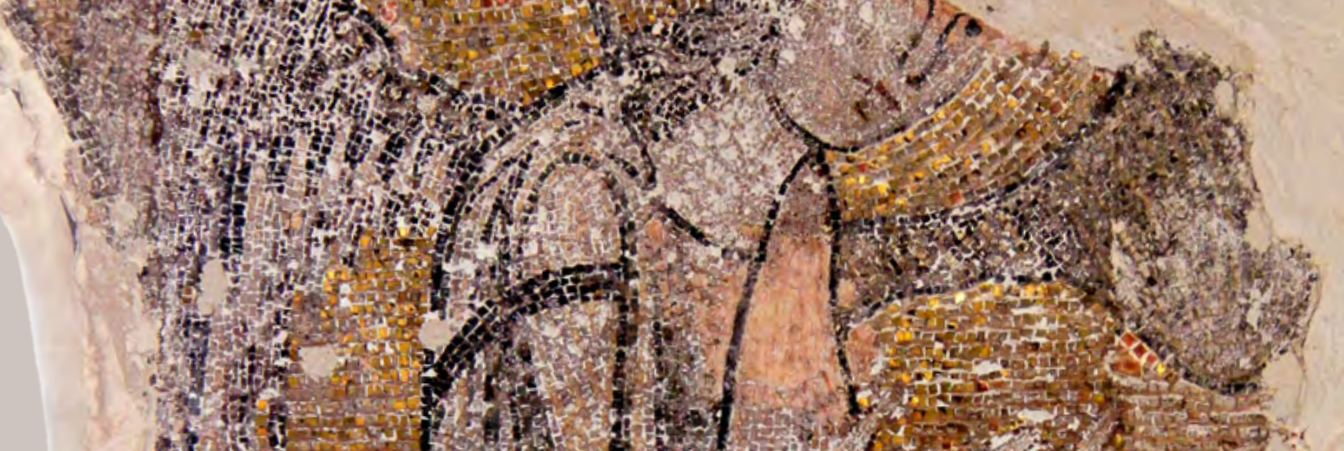

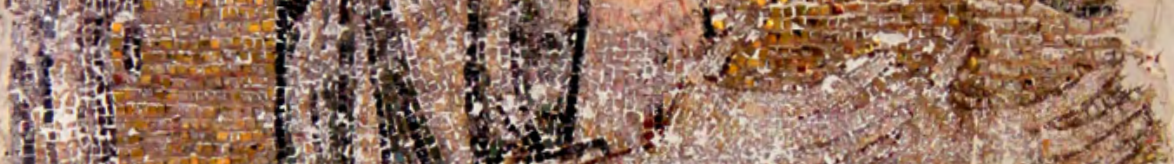

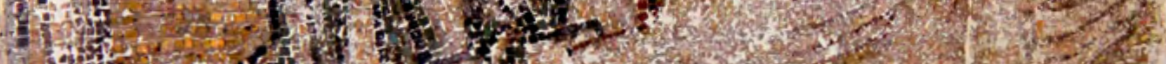
(1) Q.

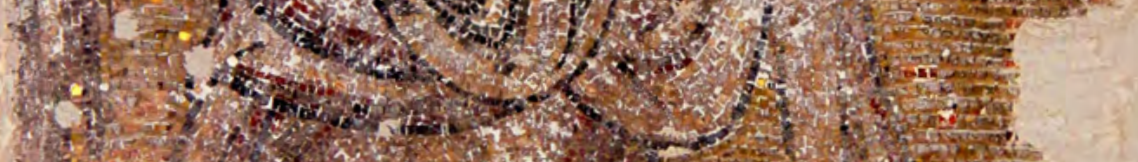

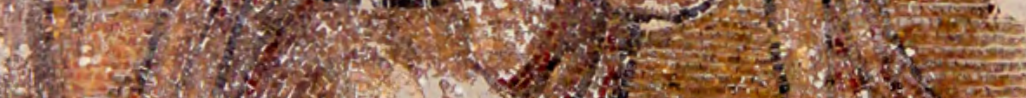

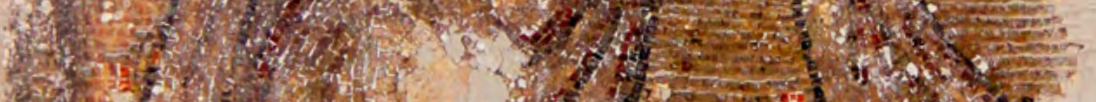

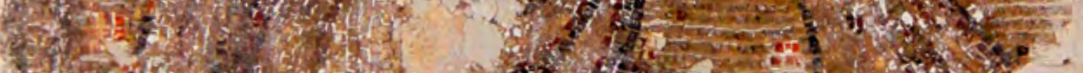

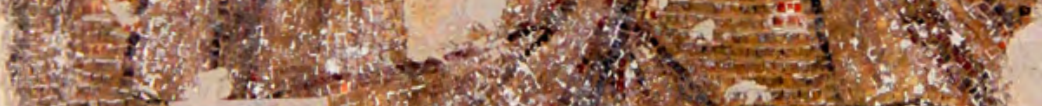

15/The newly

rediscovered angel figure between windows, mosaic, north wall of the nave, Nativity church, Bethlehem, ca $1155^{-1169}$
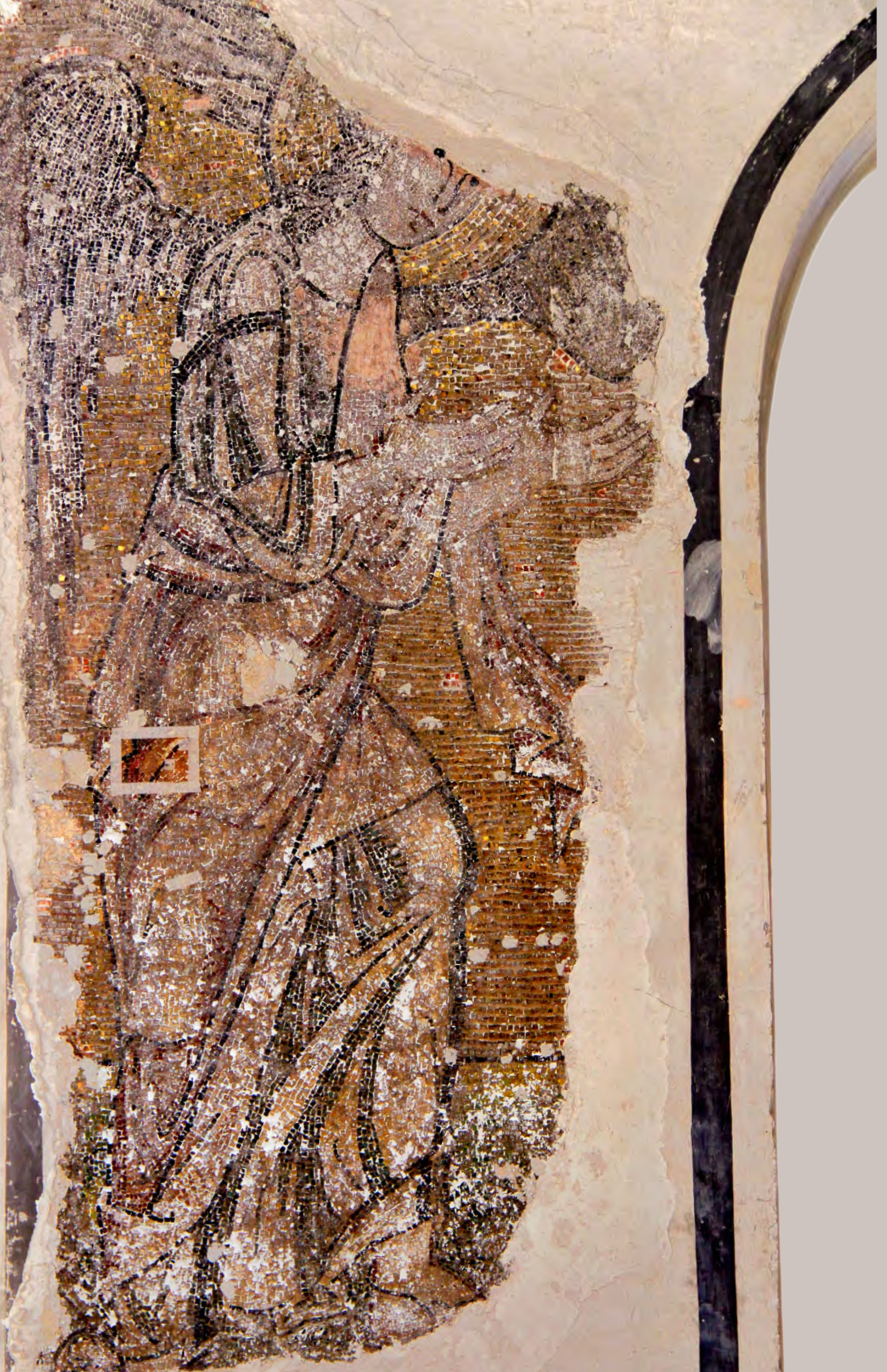


\section{Restaurátorské práce a nové objevy v Chrámu Narození Páně v Betlémě}

V roce 2010 byl mezinárodní tým vědců vedený profesorem Claudiem Alessandrim z Ferrarské univerzity pověřen Palestinskou autonomií provedením průzkumu, který měl být předstupněm rekonstrukce střechy Chrámu Narození Páně v Betlémě. Projekt, na němž spolupracovali restaurátoři, odborníci na ochranu kulturního dědictví, architekti, historici umění a archeologové, se ukázal být výjimečnou př́ležitostí k uspořádání nového strukturálního výzkumu, k provedení různých druhů analýz a sesbírání množství nových dat. Zároveň byla takto připravena půda pro první fázi restaurátorských prací, které byly v roce 2013 zahájeny přestavbou dřevěné střechy a následně pokračovaly zpevněním Arménských dveří a dalších dřevěných prvků. $\mathrm{V}$ roce 2015 započalo čištění mozaik z 12. století, které vedlo $\mathrm{k}$ objevu částí dekorací, jež byly v roce 1842 ukryty pod silnou vrstvu omítky, a to včetně velké postavy anděla na severní stěně hlavní lodi.

Tento článek, sepsaný jedním ze členů týmu, se věnuje některým z nejvýznamnějších výsledků této pětileté práce. Vůbec poprvé zveřejňuje nedávno objevené části mozaiky a vyjadřuje se o jejich stylistických a ikonografických specifikách. Nové objevy jsou chápány jako poslední fáze kontinuálního procesu proměn chrámového prostoru, probíhajícího již od období křížových výprav. Osud těchto mozaik, jejich postupné chátrání a dopad stavu dochování na způsob jejich vnímání, jakož i na uměleckohistorickou debatu, jsou zde rekonstruovány v kontextu svého dějinného vývoje, na základě svědectví zprostředkovaných záznamy poutníků a dalšími historickými prameny. 